\title{
Neutrophils: Many Ways to Die
}

\author{
Erandi Pérez-Figueroa ${ }^{1,2}$, Pablo Álvarez-Carrasco ${ }^{2}$, Enrique Ortega ${ }^{2}$ and \\ Carmen Maldonado-Bernal ${ }^{1 *}$ \\ 1 Unidad de Investigación en Inmunología y Proteómica, Hospital Infantil de México Federico Gómez, Secretaría de Salud, \\ Mexico City, Mexico, ${ }^{2}$ Departamento de Inmunología, Instituto de Investigaciones Biomédicas, Universidad Nacional \\ Autónoma de México, Ciudad Universitaria, Mexico City, Mexico
}

OPEN ACCESS

Edited by:

Jan Fric,

International Clinical Research Center (FNUSA-ICRC), Czechia

Reviewed by:

Meraj Alam Khan,

Hospital for Sick Children, Canada

Franca Marino,

University of Insubria, Italy

*Correspondence:

Carmen Maldonado-Bernal cmaldobe@yahoo.com

Specialty section:

This article was submitted to

Molecular Innate Immunity,

a section of the journal

Frontiers in Immunology

Received: 21 November 2020

Accepted: 08 February 2021

Published: 04 March 2021

Citation:

Pérez-Figueroa E, Álvarez-Carrasco P,

Ortega $E$ and Maldonado-Bernal $C$

(2021) Neutrophils: Many Ways to Die.

Front. Immunol. 12:631821.

doi: 10.3389/fimmu.2021.631821
Neutrophils or polymorphonuclear leukocytes (PMN) are key participants in the innate immune response for their ability to execute different effector functions. These cells express a vast array of membrane receptors that allow them to recognize and eliminate infectious agents effectively and respond appropriately to microenvironmental stimuli that regulate neutrophil functions, such as activation, migration, generation of reactive oxygen species, formation of neutrophil extracellular traps, and mediator secretion, among others. Currently, it has been realized that activated neutrophils can accomplish their effector functions and simultaneously activate mechanisms of cell death in response to different intracellular or extracellular factors. Although several studies have revealed similarities between the mechanisms of cell death of neutrophils and other cell types, neutrophils have distinctive properties, such as a high production of reactive oxygen species (ROS) and nitrogen species (RNS), that are important for their effector function in infections and pathologies such as cancer, autoimmune diseases, and immunodeficiencies, influencing their cell death mechanisms. The present work offers a synthesis of the conditions and molecules implicated in the regulation and activation of the processes of neutrophil death: apoptosis, autophagy, pyroptosis, necroptosis, NETosis, and necrosis. This information allows to understand the duality encountered by PMNs upon activation. The effector functions are carried out to eliminate invading pathogens, but in several instances, these functions involve activation of signaling cascades that culminate in the death of the neutrophil. This process guarantees the correct elimination of pathogenic agents, damaged or senescent cells, and the timely resolution of the inflammation that is essential for the maintenance of homeostasis in the organism. In addition, they alert the organism when the immunological system is being deregulated, promoting the activation of other cells of the immune system, such as B and $T$ lymphocytes, which produce cytokines that potentiate the microbicide functions.

Keywords: cell death, apoptosis, pyroptosis, necroptosis, necrosis, NETosis, autophagy, neutrophils

\section{INTRODUCTION}

Neutrophils, also denominated microphages or polymorphonuclear leukocytes (PMN), are granulocytes that are the most abundant leukocyte type in the peripheral human blood, constituting from 40 to $70 \%$ of the total white blood cells under normal conditions (1). Their half-life is short, from 8 to $20 \mathrm{~h}$ in circulation, although after migration into tissues, their life is considerably prolonged (1-4 days) (2). They comprise the first cells of the immune system to arrive at the 
infection site and are characterized by their potent antimicrobial and antifungal capacity, which is granted by their cellular components: antimicrobial peptides, neutrophil-specific proteolytic enzymes, as well as their production of ROS and neutrophil extracellular traps (NETs) (3-5).

Neutrophils contain an extraordinary array of receptors for the recognition of pathogens, including membrane receptors such as scavenger receptors $(6,7)$, mannose receptors (8), Dectin-1 (9), CD14 (10, 11), C1qR (12), receptors for IgG (Fc $\gamma \mathrm{R})$ (13-16), C3b/C3biRs (CR1,CR3) (17), collectins (CD91calreticulin complex) $(18,19)$, and Toll-like receptors (TLRs) (20); they also express intracellular receptors such as NODlike receptors (NLRs) (21). Through these receptors, known as pattern recognition receptors (PRRs), neutrophils are activated to respond to infections or to damage signals. PMNs also contain enzymatic machinery for the production of free radicals that allows a much more effective elimination of pathogens (22). At the same time or after performing their effector functions, neutrophils initiate mechanisms of cell death such as autophagy, NETosis, or apoptosis. Cell death of neutrophils is an indispensable event required to maintain the number of neutrophils in infection or inflammation and in an organism in homeostasis (23-25).

The regulation of neutrophil death rate is an essential mechanism for maintaining homeostasis under physiological conditions. Their accelerated death, either idiopathic or acquired (e.g., drug-induced), leads to a decrease in the total count (neutropenia) increasing the probability of contracting bacterial or fungal infections and negatively affecting their resolution $(26,27)$. In contrast, delays in the death of neutrophils raises their count (neutrophilia) (28). Neutrophilia is a classic indicator of acute inflammation related to acute atherosclerotic events or trauma. For these reasons, the regulation of neutrophil survival is essential in the inflammatory process. The following review brings together recent findings related to the mechanisms that regulate the death of neutrophils, as well as the intrinsic and extrinsic signals that initiate these processes.

\section{REVIEW}

\section{Processes of Cell Death Apoptosis}

The cells of an organism are capable of dying through a mechanism of programmed cell death denominated apoptosis, characterized by changes in the cell structure, such as the acquisition of an elongated shape, retraction of the pseudopods, reduction of the cell volume (pyknosis), and chromatin condensation, with scarce or null structural modification of the cytoplasmic organelles. Other changes include DNA fragmentation with or without oligonucleosomal fragmentation, and usually activation of caspases (29-31). Apoptosis occurs with minimal damage to the surrounding tissue.

In neutrophils, this process is initiated by either of two distinct signaling pathways: the intrinsic or the extrinsic apoptotic pathway. In the intrinsic pathway, permeabilization of the mitochondrial membrane, due to the absence of antiapoptotic factors, leads to the release of cytochrome $\mathrm{C}$ to the cytoplasm.
Once in the cytoplasm, the cytochrome $\mathrm{C}$ participates in the assembly of a multimeric complex denominated apoptosome and the subsequent activation of the effector caspase (caspase3). On the other hand, the extrinsic pathway is activated in response to extracellular ligation of death receptors, resulting in the activation of caspase- 3 by means of the activation of caspase- 8 $(28,29,32,33)$.

In this first phase of the death process, the neutrophils are no longer functional since their chemotaxis, respiratory burst, and degranulation are impaired $(34,35)$, in addition to a decrease in the expression of surface receptors and adhesion molecules (36, 37) and a significant reduction in the release of chemokines (38).

It is also known that neutrophil apoptosis can be delayed or accelerated depending on specific cellular stimuli. According on the inflammation conditions, the neutrophil response to microorganisms can change significantly: while some pathogens initiate the spontaneous apoptotic process, others engage in such tight interactions that cause apoptosis followed by cell lysis $(39,40)$. The apoptotic death process, as opposed to the necrotic death process, maintains membrane integrity to limit the release of harmful neutrophil contents. The exposure of phosphatidylserine (PS) residues on the cell membrane allows for greater recognition by macrophages, thereby enhancing the clearance of the cells. It also increases the production of IL-10 and TGF- $\beta$ in macrophages, cytokines associated with resolving the inflammatory response and promoting tissue repair $(41,42)$.

In contrast, the life span of neutrophils can be considerably extended under certain inflammatory conditions, such as in the presence of granulocyte-colony stimulating factor (G$\mathrm{CSF}$ ), granulocyte-monocyte colony-stimulating factor (GMCSF), Interleukin 8 (IL-8), and C reactive protein, among other proinflammatory mediators (43-46).

Apoptosis is a non-inflammatory process of cell death activated in senescent neutrophils by cytokines and growth factors inducing the PI3-K/Akt, BCL-2/BCL-X $\mathrm{L}_{\mathrm{L}}$, and p53/p21 pathways, in a similar way as it occurs in other cells $(32,47$, 48). However, this is not the only way to activate apoptosis in neutrophils. It is recognized that apoptosis pathways can be activated in neutrophils after phagocytosis and ROS production, or during inflammatory processes when molecules such as extracellular matrix proteins (49), lipopolysaccharide (LPS), complement fragments (44), and cytokines, among others, favor the activation of TNF receptors and FaS/CD95 through JNK and NF-kB $(50,51)$.

The high concentrations of reactive oxygen species produced by the NADPH oxidase are an important marker for triggering apoptosis or necrosis. In resting neutrophils, the NADPH is inactive and its components are distributed between the cytosol and cellular membranes. Upon neutrophil activation, the cytosolic components (p47phox, p67phox, p40phox) and the Rho family GTPase Rac-2 migrate toward the membranes of intracellular granules and the cell membrane (52) to participate in the assembly of the NADPH oxidase complex, which mediates the metabolic burst and ROS production. In the last years, it has been suggested that ROS produced by the NADPH oxidase participate as signaling molecules and it has been shown that the 
molecular pathways leading to apoptosis of neutrophils depend on ROS generation (53-55).

Kinases such as AKT and JNK regulate apoptosis-NETosis pathway in a ROS production-dependent manner. Activated AKT leads to NETosis, however its inhibition lead neutrophils to apoptosis (56) while JNLK is an important molecular sensor that initiates NETosis in response to increasing concentrations of LPS- and Gram-negative bacteria $(57,58)$. Recent studies show that apoptosis can occur along with NETosis, when neutrophils are stimulated with ultraviolet (UV) irradiation, calling it ApoNetosis. This type of death activates caspase 3 and is NOX-independent, though this interesting development requires further investigation (59).

\section{Necroptosis}

While apoptosis is one of the most studied forms of cell death in different cellular lineages, necroptosis is another type of programmed cell death that is not so well-known. This type of death is a regulated process, which depends on receptor interacting protein kinase-3 (RIPK3) and mixed lineage kinase domain-like protein (MLKL) (60-62).

While necroptosis is a process of programmed cell death, it does not involve the precise morphological changes characteristic of apoptosis and, importantly, it does not involve DNA fragmentation. Diverse forms of activation of neutrophils have been found to culminate in this process. Stimuli such as the activation of cell death receptors like TNFR1, ligation of TLRs, IFNGR, adhesion receptors such as CD11b, CD15, or CD18, the presence of monosodium urate (MSU) crystals, and the phagocytosis of Staphylococcus aureus, have been shown to initiate activation pathways that culminate in the activation of the RIPK3-MLKL complex (62-67). The signaling events upstream of the activation of the RIPK3-MLKL complex are different depending on the receptor involved. The activation pathway initiated through the TNFR1 is probably the best-characterized one (68). The activation of the receptor induces the formation of a complex with RIPK1, whose ubiquitination through diverse proteins, such as the cellular inhibitors of apoptosis [cIAP] and the linear ubiquitin chain assembly complex [LUBAC]) (6971), activate the NF- $\mathrm{KB}$ survival factor, thus contributing to cell survival, proliferation, and production of proinflammatory cytokines; if ubiquitination of RIPK1 is inhibited, a different complex is formed that recruits caspase- 8 , inducing apoptosis (72); however, if the activity of caspase- 8 is inhibited, then RIPK1 recruits RIPK3 in a complex called the necrosome. This complex can now recruit the caspase- 8 in order to give rise to the necroptotic process (73-75).

In the case of activation of adhesion receptors or the presence of MSU crystals, the activation of necroptosis depends on the formation of ROS inside the cell, although the mechanism by which ROS induce the activation of the RIPK3-MLKL complex has not been not established. However, intracellular production of ROS is indispensable for necroptosis, as neutrophils of patients with chronic granulomatous disease are incapable of entering into necroptosis through the adhesion molecules $(62,76)$. In the case of MSU, there is evidence that relates necroptosis with the release of neutrophil extracellular traps (NETs); this stimulus is linked with the formation of ROS by inducing the assembly and activity of the NADPH oxidase complex. It was observed that the inhibition of RIPK3, as well as the action of other necroptosis inhibitors, diminished the formation of NETs induced by MSU crystals, thus confirming the relation of necroptosis with NETosis, at least after this stimulus (77).

\section{Necrosis}

Adverse environmental conditions, such as lack of oxygen or essential nutrients, high temperature, toxic compounds, and mechanical stress, can initiate necrosis. In contrast with apoptosis, there is a gain in cell volume (oncosis), rupture of the plasma membrane, and release of intracellular material to the surrounding milieu during necrosis $(78,79)$; similarly, there is swelling of cytoplasmic organelles (mitochondria, endoplasmic reticulum, and Golgi), moderate chromatin condensation, the absence of the activation of caspases, release of cytochrome c, and fragmentation of oligonucleosomal DNA. Morphologically, these have been defined as the spectrum of post-mortem changes of a tissue due to the progressive action of the enzymes released by the damaged structures (79). The morphology of the necrotic cells results from the denaturation of proteins and the autolytic or heterolytic enzymatic digestion $(30,31,79)$.

The habitual participants in necrotic cell death, independently of the stimulus, are $\mathrm{Ca}^{2+}$ ions and ROS. During necrosis, the levels of cytosolic $\mathrm{Ca}^{2+}$ rise, leading to an overload of calcium in the mitochondria and the activation of proteases and phospholipases (80). ROS generate damage to lipids, proteins, and DNA; consequently, there is mitochondrial dysfunction, deregulation of the ionic equilibrium, and loss of membrane integrity. Destabilization of the membrane during necrosis is also mediated by other factors, such as acid sphingomyelinase (SMA), phospholipase A (PLA), and the calpains. In addition, necrotic cells release immunomodulatory factors that lead to their recognition and trapping by phagocytes, which can promote a subsequent immunological response.

Necrotic neutrophils, as well as other cells such as monocytes and dendritic cells, can activate NF- $\mathrm{KB}$ in neighboring cells (like fibroblasts or macrophages), stimulating the production of IL-6, IL-8, and TNF- $\alpha$ (81). The stimuli that induce this type of cell death of neutrophils are mainly pathogens that prompt a ligand-receptor response, giving rise to a high concentration of intracellular ions, as well as to the release of proinflammatory cytokines since the external stimulus. TNF$\alpha$ secreted by activated neutrophils or other cells can activate neutrophil necrosis, although membrane proteins can regulate this with enzymatic activity, such as aminopeptidase N (CD13) $(82,83)$.

\section{NETosis}

In 2004, the discovery of neutrophils extracellular traps (NETs) established a mechanism of effector response specific of these cells (84). However, it was later demonstrated that all granulocytes possess this capacity after treatment with IL-5 and IFN- $\gamma$ or with GM-CSF and C5a (85). The release of NETs is part of a programmed cell-death process denominated NETosis. In contrast with apoptosis or necrosis, the nuclear 
membrane and the cellular membrane disintegrate; however, the cytoplasm contents remain integrated for a moment, allowing the interaction of the antimicrobial granule proteins with the DNA $(86,87)$. On releasing its genetic material, the extracellular chromatin functions for immobilizing the bacteria and preventing its dispersion through the host tissues. Simultaneously, these traps are capable of degrading virulent bacterial products like IcsA, a key virulence factor of the human pathogen Shigella flexneri (88) or IpaB (invasive plasmid antigen B) $(89,90)$. These bacterial products and their subproducts can induce inflammation and diverse chemotactic signals that result in the recruitment of monocytes and other cells to the infection site $(84,86,91)$.

The process of NETosis can be induced by an extensive number of stimuli that include pathogenic microorganisms, activated platelets (92), pathogen's structures, formylated peptides, and cytokines, among others. Signals characteristic of apoptosis, such as the condensation of genetic material, the presence of phosphatidylserine (PS) in the membrane, and activation of caspases, are not observed during NETosis (93).

This process is regulated, among others, by peptidyl arginine deaminase 4 (PAD4), an enzyme that contains a putative sequence of nuclear localization, but that resides principally in cytosolic structures in resting neutrophils, although it can also enter into the nucleus and citrullinate the histones and diverse transcription factors. Therefore, it can participate in the epigenetic regulation of gene expression and cellular differentiation $(94,95)$. PAD4 is associated with the cytosolic subunits $47^{\text {phox }}$ (also known as neutrophil cytosolic factor 1 , NCF1) and p6 $7^{\text {phox }}$ (NCF2) that form part of the NADPH oxidase complex involved in the respiratory burst. Activation of the cell leading to the elevation of intracellular $\mathrm{Ca}^{2+}$ to physiological levels do not result in activation of PAD4 enzymatic activity. However, high levels of intracellular calcium (higher than those of physiological neutrophil activation, such as those observed by disruption of the cell membrane) lead to activation of PAD4 and rapid citrullination of p47phox/NCF1 and p67phox/NCF2, as well as their dissociation from PAD4. Citrullination of NCF1 and NCF2 prevents the assembly of NADPH oxidase complex (95). Originally, it was reported that the presence of NADPH oxidase and myeloperoxidase (MPO) was necessary for the correct formation of NETs; until recently, all the activators capable of inducing NETs formation were known to require in some manner the presence of ROS (96). However, this has been a controversial theme in recent years due to the description of novel NETosis activation pathways that appear to be independent of NADPH oxidase $(81,97,98)$.

PAD4 citrullinates chromatin, specifically histones, catalyzing the deimination of the arginine at the amino terminal end of the $\mathrm{H} 3$ subunit. This reduces the attraction of heterochromatin protein HP1B to H3-adjacent lysine 9, resulting in the formation of dispersed chromatin. In addition to this, neutrophil elastase (NE) and MPO complement the decondensation of chromatin. Both NE and MPO are stored in azurophilic granules that are released once ROS are formed in the cell. NE is a PMNspecific serine protease that degrades virulence factors and is bactericidal. However, during the process of NETosis, it enters the nucleus and cleaves the histones, promoting greater chromatin decompactation (99). Later during the NETosis process, when the NE have already acted, MPO binds to the chromatin prompting even a greater decompactation. The synergic process of these enzymes for the formation of dispersed chromatin reaches the point at which the nuclear and cellular membranes break and NETs are released (100). Interestingly, the most abundant component of the NETs are histones and these are one of the most potent antimicrobial factors $(96,101)$.

Activated neutrophils produce large amounts of superoxide through the NADPH oxidase. Superoxide is then converted into hydrogen peroxide $\left(\mathrm{H}_{2} \mathrm{O}_{2}\right)$ leading to the formation of a variety of toxic oxygen derivatives. MPO catalyzes the oxidation of halides by means of hydrogen peroxide. Both, the NADPH oxidase and MPO, have been implicated in regulating NETs formation. It is now known that the ROS generated through the NADPH oxidase prevent activation of caspases (102) and that NADPH oxidase is necessary for the formation of NETs through many (though probably not all) stimuli.

Participation of the Raf-MEK-ERK pathway in the formation of NETs has been identified by the phosphorylation of ERK1, ERK2, and c-Raf. Since the inhibition of the NADPH oxidase does not block the phosphorylation of these proteins induced by PMA, this suggests that activation of the Raf-MEK-ERK pathway is found upstream of NADPH oxidase activation $(103,104)$.

NETs formation depends directly on the intensity of the stimulation of the cell and on the time of exposure to the stimulus. Currently, NETosis continues to be considered a process of cell death, although some studies have demonstrated a process known as vital NET formation, in which neutrophils release mitochondrial DNA, which does not compromise their viability $(105,106)$.

\section{Pyroptosis}

This pathway of cell death is dependent on caspase-1. This caspase is not involved in apoptotic cell death and its function is to process the precursors of the IL- $1 \beta$ and IL-18 inflammatory cytokines through the multiprotein complex called inflammasome $(107,108)$. This type of cell death is observed, e.g., in cells infected with Salmonella, in which the activation of caspase- 1 is produced by effector substances released into the cytoplasm of host0 cells through the Salmonella Pathogenicity Island 1 Type III Secretion Systems (SP1 T3SS).

The assembly and function of an inflammasome are essential for the process of pyroptosis; these oligomeric complexes serve as a molecular platform for the key step of the process, that is, the cleavage of pro-CASP-1 zymogen into active caspase- 1 . Canonical inflammasomes are composed of cytoplasmic pattern recognition receptors (PRR), which include NLRs, absent in melanoma 2 (AIM-2)-like receptors (ALRs), adapter protein apoptosis-associated speck-like protein containing a CARD (ASC), and pro-caspase-1 $(109,110)$. Numerous canonical inflammasomes have been recognized in pyroptosis including NLRP1, NLRP3, AIM2, NLRC4, and Pyrin inflammasomes (111116).

Activation of caspase-1 results in the formation of pores in the plasma membrane and the cell becomes permeable to 
small-molecular-weight colorants such as 7-aminoactinomycin (7-AAD), ethidium bromide (EtBr), and propidium iodine (PI). In contrast, the cell membrane in an apoptotic cell remains intact and the cells fragment into apoptotic bodies that are not stained with 7-AAD nor with PI (108). Activation of caspase-1 leads to DNA fragmentation and to cell lysis by separate pathways. DNA fragmentation is carried out by an unidentified caspase 1 -activated nuclease that does not involve the degradation of ICAD (inhibitor caspase-activated deoxyribonuclease) $(117,118)$ that, together with rearrangements of the actin cytoskeleton, are events required for the formation of membrane pores of between 1.1 and $2.4 \mathrm{~nm}$ in diameter (119). In addition, caspase-1 cleaves the precursors to produce biologically active IL-1B and IL-18, which come out easily through the pores. Dissipation of the cellular ionic gradients leads to a flow of water with cellular tumefaction and osmotic lysis (120), releasing the intracellular (proinflammatory) contents. Even so, according to some researchers, pyroptosis comprises nothing more than a caspase-1-dependent necrotic-type death.

Pyroptosis has been mainly described in macrophages and dendritic cells. However, there is evidence of caspase-1 activity in other cell types. Many pathogens can survive and replicate within the macrophages; however, very few pathogens can do this in neutrophils. This is probably due to intrinsic differences between the two cell types. Macrophages have a longer life but reduced microbicidal activity as compared to neutrophils, which converts them into a more infection-prone cellular objective. Neutrophils, on the other hand, are highly microbicide and short-lived, which makes them poor targets for intracellular pathogens.

During acute Salmonella infection, neutrophils can activate the NLRC4 inflammasome to produce IL-1 $\beta$, without undergoing pyroptosis, and thus they can continue their inflammasomeindependent antimicrobial effector functions while maintaining IL-1 $\beta$ secretion $(121,122)$. This can suggest that neutrophils do not undergo pyroptosis in response to proteins of some intracellular pathogens (such as flagellin or the proteins making up T3SS) that activate assembly of NLRC4 inflammasome. However, it has been determined that neutrophils can undergo pyroptosis, activating a non-canonical infammasome pathway through P2X7 receptors in absence of NOX2 in pseudomonal infections $(105,123,124)$.

\section{Autophagy}

The term autophagy derives from the Greek to eat (phagy) oneself (auto), that is, self-digestion. This is a highly conserved process in evolution that takes place in all eukaryotic cells, from yeasts to mammals. It occurs in response to different forms of stress, such as lack of nutrients, absence of growth factors, infectious processes, or hypoxia. Therefore, it is possible that the main function of this process is to provide necessary nutrients to maintain the vital functions of the cell in situations of energy or nutrient deprivation. Additionally, some studies point out that the process denominated "selective autophagy" is also utilized to remove "dangerous" material in the cytoplasm, such as damaged mitochondria or protein aggregates (125). To date, three distinct forms of autophagy have been identified, macroautophagy, microautophagy, and selectiveautophagy (126).
Autophagy is characterized by the formation of autophagic intracellular vesicles and the degradation of cellular contents, including essential organelles such as mitochondria, inside the vesicles. Many of the PRRs, including TLRs and NLRs, induce autophagy in macrophages (127). Similarly, neutrophils undergo autophagy in response to TLR ligands. Apparently, autophagy in neutrophils can be induced dependently or independently of phagocytosis $(128,129)$.

Autophagy in the neutrophil is a mechanism of survival. Pliyev and Menshikov (130) demonstrated that inhibitors of autophagy, such as 3-methyladenine (MA) and chloroquine (CQ), notably accelerate the spontaneous apoptosis of neutrophils as evidenced by exposure of phosphatidylserine, DNA fragmentation, and the activation of caspase-3. It has also been observed that human neutrophils can be induced to autophagy by simultaneous stimulation by sialic acid binding immunoglobulin-like lectin-9 (Siglec-9) ligation and certain cytokines with survival-promoting activity in neutrophils (131). Some studies have demonstrated that adhesion molecules induce death in neutrophils independently of caspases. The process is characterized by great cytoplasmic vacuolization and the fusion of organelles, thus, it has been associated with autophagy (132) Neutrophils with morphological signs of autophagy have been observed in septic shock, cystic fibrosis, rheumatoid arthritis, and various skin diseases, suggesting that the induction of autophagy in polymorphonuclear leukocytes comprises a general phenomenon in their response to inflammation (133). It has also been demonstrated that the inhibition of autophagy diminishes NETosis, avoiding chromatin decondensation and resulting in a cell death characterized by signs of apoptosis $(134,135)$.

Autophagy in neutrophils is activated by phagocytosis of pathogens or activation of pattern recognition receptors (PRRs) that induce non-canonical selective autophagy during bactericidal activity by pathogen-derived toxins and molecules that damaged organelles such as mitochondria or peroxisomes resulting in specific fusion of lysosomes with these organelles (136-139).

The fact that LPS or phagocytosis of opsonized particles can induce autophagy in neutrophils independently of the formation of NETs, suggests that it is an additional effector mechanism that is independent of other responses to pathogens (140); however, the molecular mechanisms responsible for this remain unclear and in dispute. In this manner, bacteria that could escape from the phagolysosome may become exposed to the degradative proteases present in autophagosomes (132).

\section{Phagocytosis}

Phagocytosis is an important physiological mechanism that allows the elimination of excess cells or damaged cells and, in cases of infection by pathogens, their elimination. Because many of the eat-me signals are displayed on necrotic cells or cells in the process of apoptosis, it was thought that phagocytes only feed on dead cells or cells condemned to die (141). However, there is now evidence that phagocytosis of viable cells can cause their death, a process that has been termed primary phagocytosis or phagoptosis $(142,143)$. 
The process of phagocytosis of apoptotic neutrophils is normally initiated with exposure of the phospholipid, phosphatidylserine (PS) (the "eat-me" signal). In healthy cells, PS is found nearly exclusively in the internal leaflet of the plasma membrane but, in apoptotic cells, it becomes exposed on the outer side through the action of a phospholipid scramblase. Exposure of PS can take place because of the following diverse processes:

The increase of intracellular $\mathrm{Ca}^{2+}$ ions that stimulates the scramblase and inhibits the translocase of phospholipids (flippase).

Depletion of ATP, which inhibits the translocase.

Oxidative stress, which stimulates the scramblase and inhibits the translocase.

The fusion of intracellular vesicles with the plasma membrane. Necrosis due to the rupture of the plasma membrane, an increase of intracellular calcium or depletion of $\operatorname{ATP}(144,145)$.

Activated macrophages can induce the exposure of PS on viable neutrophils (independently of apoptosis). PS exposure can then promote their phagocytosis, which is facilitated by the PSbinding proteins MFG-E8 (Milk fat globule-EGF factor 8 protein) and Annexin 1 (146).

The plasminogen activator inhibitor 1 (PAI-1) acts as a "don't-eat-me" signal in neutrophils as phagocytosis of viable neutrophils of PAI-1 knockout mice by macrophages was increased when compared to that of neutrophils from wild type mice. On the other hand, when PAI-1 or its receptor (CD47) are blocked, calreticulin (CTR) acts as the main "eat-me" signal and the lipoprotein receptor-related protein (LRP) (147) mediates phagocytosis.

Changes in the microenvironment of the neutrophil after having initiated a phagocytic process can lead to cell death. Neutrophils are exceptionally efficient phagocytes and are capable of gobbling up a prey opsonized with IgG in $<20 \mathrm{~s}$, in comparison with macrophages, which need up to several minutes to ingest similar amounts of opsonized particles (148). In neutrophils, the recruitment of NADPH oxidase during phagosome maturation is significantly higher than in macrophages due to the fusion of cytoplasmic granules with the phagosome $(149,150)$. These, and probably other mechanisms, result in the neutrophil phagosome to retain a $\mathrm{pH}$ close to neutral for longer periods of time, in comparison with the maturation of the phagolysosome in macrophages, in which acidification can reach $\mathrm{pH}$ values of $4.5-5(151,152)$.

It was reported that after phagocytosis of heat-killed Escherichia coli, the intracellular $\mathrm{pH}$ is crucial to determine the fate of the neutrophil and that the $\mathrm{pH}$ depends on the pathogen: phagocyte ratio; mild acidification of $\mathrm{pH}$ leads to cell apoptosis, but conditions of high bacterial concentrations that induce a larger decrease in $\mathrm{pH}$ lead to necrosis (153). In the case of virulent Staphylococcus aureus strains, it was shown that its phenol-soluble modulin (PSM) alpha proteins cause necrosis of neutrophils after phagocytosis, increasing the survival rate of the bacteria $(154,155)$. It is known that $\mathrm{TNF} \alpha$, influenza virus, as well as the virulence factors of E. coli, Mycobacterium tuberculosis, and other microorganisms, promote the death of neutrophils (156-158). In the majority of cases, this occurs after certain virulent factors are able to escape from the phagosome, activating cell death pathways such as necrosis or pyroptosis. As mentioned earlier, pyroptosis is mediated by the inflammasome, which is assembled after the phagocytized bacteria escape from the phagosomes and the bacterial products are detected by PRRs in the cytosol $(159,160)$.

\section{INTRACELLULAR MEDIATORS OF THE CELL DEATH OF NEUTROPHILS}

\section{Free Radicals}

In a normal process and under the appropriate stimuli, neutrophils are capable of releasing cytotoxic mediators, such as ROS and RNS, generating damage to pathogens but also to the host's tissues. After the elimination of the proinflammatory stimuli, repaiment of the damaged tissue is necessary to return the tissue to a homeostasis state. At this point, anti-inflammatory signals start to be released contributing to the resolution of inflammation, and neutrophils in the tissue should enter apoptosis and be ingested by macrophages in order to clean the inflamed area. Apoptosis of neutrophils is regulated by intracellular mediators and extracellular signals; among the intracellular mediators are the ROS, mainly produced by the NADPH oxidase of the activated neutrophils $(161,162)$, although some reports show that ROS can be generated by mechanisms that are independent of the NADPH oxidase. Thus, it was reported that the production of superoxide and hydrogen peroxide can be mediated by low-conductance, calcium-activated potassium channels known as SK (small conductance) channels $(163,164)$. Another way of generating ROS in the neutrophil is through the accumulation of electrons of the respiratory chain, linked to a low activity of complex IV due to the low levels of cytochrome c $(16,165-167)$. Decreasing intracellular ROS levels by reduced glutathione (GSH), as well as by catalase, inhibits the death of neutrophils $(39,168,169)$.

ROS have the capacity to damage DNA generating cell death through direct or indirect activation of p53 (170). ROS can also induce activation of the inflammasome, formed by NLRs, an adaptor molecule, and caspase-1 $(171,172)$. However, ROS can directly alter the activity of the intracellular signaling pathways implicated in the death and survival of neutrophils, such as NF$\kappa \mathrm{B}$ and MAPK (mitogen-activated protein kinases) $(173,174)$. In fibroblasts, ROS cause oxidation and inhibition of JNKinactivating phosphatases, promoting JNK activation, release of cytochrome c, and the subsequent activation of caspase-3 (175, 176). Similarly, it has been demonstrated that the accumulation of ROS results in the grouping of death receptors in lipid rafts and the activation of caspase-8, independently of the Fas ligand (29). The generation of intracellular (but not phagosomal) ROS, caused by neutrophil activation, triggers the process of apoptosis, while the production of intraphagosomal ROS during phagocytosis does not have this effect. This suggests that the location of the production of ROS is fundamental for inducing the death of neutrophils (177). Among the molecules involved in 
the regulation of ROS production after cell activation, is Bruton's tyrosine kinase (Btk). The absence of this kinase induces a greater production of ROS by hyper phosphorylation and activation of phosphatidylinositol-3-OH-kinase (PI3K) and protein tyrosinekinases (TKPs) (178). In addition, the levels of free radicals can be elevated by nitric oxide synthase (NOS) through the production of nitric oxide (NO) $(177,179)$. In recent years, it has been demonstrated that NO has also the capacity to induce apoptosis in neutrophils (180). It has been shown that the derivative of oxatriazol-5-amine, PGE 3162, and SIN-1 increase the rate of apoptosis in human neutrophils, correlating with data of the greater DNA fragmentation and cell death in neutrophils treated with exogenous NO $(181,182)$. Interestingly, high levels of ROS or RNS in neutrophils inhibits the activity of the caspases, suggesting the existence of an alternative, caspase-independent cell-death pathway $(177,179,183,184)$.

\section{Caspases and Calpains Involved in Apoptosis}

Most stimuli that lead to apoptosis converge in the mitochondria inducing the permeabilization of their external membrane. With permeabilization, a series of proteins are released that activate the caspases (185), which carry out the majority of the proteolytic events of apoptosis and are considered as the ultimate responsible for cell death. Caspases are localized in the form of procaspases in the cytoplasm and the intermembrane space of the mitochondria. Procaspases are activated by cleavage and act as executors cleaving cellular survival molecules triggering processes that induce cell death. Caspases are regulated at the post-translational level and possess a classic structure consisting of a prodomain (N-terminal), a small subunit (p10) in the C-terminal, and a large subunit (p20) that contains the active center with cysteine within a QACXG-conserved motif $(186,187)$.

The initiator caspases possess prodomains larger than effector caspases. The latter contain caspase recruitment domains (CARD), as in the case of caspase- 2 or caspase-9, or cell death effector domains (DED), as in the case of caspase- 8 and caspase-10, which permits them to interact with other molecules that regulate their activation. The stimulus for cell death induces the grouping of the initiator caspases (ScaffoldMediated Activation), allowing them to transactivate by crosscleavage and, thus, proceed to activate the effector caspases. In all the studied cases, the mature enzyme is a heterotetramer that contains two p20/p10 heterodimers and two active centers (186). In neutrophils, caspases 3 and 10 play an important role in the induction of cell death (188). In Helicobacter pylori-infected neutrophils, the activity of caspase- 1 is increased, promoting its association into inflammasomes to participate in the triggering of pyroptosis (189). In neutrophils, the activity of caspase-9 also increases drastically during apoptosis (167).

The calpains are calcium-dependent cysteine proteases that can be divided into two subfamilies according to the cation concentrations necessary for their activation: micromolar for the $\mu$-calpains and millimolar for the m-calpains. They play an important role in cell proliferation, progression of the cell cycle, cell migration, and programmed cell death (190). Calpains are present in the cytosol as inactive enzymes that are activated in response to increases in the cellular concentration of $\mathrm{Ca}^{2+}$ ions. Once activated, they can modify transcription factors, cytoskeletal proteins, kinases, and proapoptotic proteins, such as Bid and Bax, into fragments incapable of interacting with antiapoptotic proteins, inducing the release of cytochrome $\mathrm{c}$ and activation of caspase-3 leading to apoptosis $(191,192)$. In human neutrophils, calpains do not only play a role in apoptosis, but calpains are also involved in the adhesion of TNF- $\alpha$-stimulated cells, and play a role in migration regulated by the cytosolic $\mathrm{Ca}^{+2}$ concentration $(193,194)$.

\section{Bcl2 and IAP (Apoptosis-Regulatory Proteins)}

The process of apoptosis in human cells is regulated by a family of diverse pro-apoptotic and anti-apoptotic proteins, with protein $\mathrm{Bcl}-2$ as the prototype protein. Members of this family are grouped into three subfamilies as follows: the antiapoptotic proteins (Bcl-2, Bcl-Xl, Mcl-1, and others), the "multidomain"type proapoptotic proteins (Bax and Bak), and the "BH3-only"type proapoptotic proteins (Bid, Bim, Bad, among others). The balance among these three groups determines susceptibility to cell death or survival as shown by the increased resistance to apoptosis of certain tumors related to the overexpression of the antiapoptotic proteins.

Another family of proteins with the ability to inhibit apoptosis (denominated IAPs) regulate the cytochrome c-caspase pathway. In humans, the following three members have been characterized: XIAP: c-IAP 1, and c-IAP 2, which bind to caspase-9 preventing its activation. In neutrophils, caspase- 9 increases its activity during apoptosis, even though the levels of cytochrome $\mathrm{c}$ in these cells are very low $(165-167,195)$. Data obtained by Murphy et al. (196) suggest that neutrophils possess a lower threshold of cytochrome $\mathrm{c}$ for the assembly of functional apoptosomes and their low content of cytochrome $\mathrm{c}$ can be compensated for by the elevated expression of apoptotic protease-activating factor 1 (Apaf-1). These further suggest that neutrophils retain a low expression of cytochrome $\mathrm{c}$ for the assembly of functional apoptosomes rather than for oxidative phosphorylation.

Neutrophils contain few mitochondria and these are found as tubular networks, and are grouped and depolarized under apoptotic conditions. Despite the relatively low levels of cytochrome $\mathrm{c}$ in these cells, the mitochondrial death pathway is functional $(167,197)$. In neutrophils, the expression of antiapoptotic molecules, such as Mcl-1 and Bcl-xl, is preferential in comparison with those of the proapoptotic protein family (198).

One of the mechanisms that regulate the transcription of the antiapoptotic proteins in neutrophils is stimulation with GMCSF and TNF- $\alpha$, which prevents the time-dependent nuclear localization of Mcl-1, and an increase in the transcription and translocation of $\mathrm{Bcl}-\mathrm{Xl}$, via stimulation of the NF- $\mathrm{KB}$ pathway. However, these cytokines also participate in the increase and maintenance of RNAm levels of BH3-only proapoptotic proteins. GM-CSF is a survival factor for neutrophils that promotes the transcription of Bim and the expression of BimeL (199). During neutrophil cell death by apoptosis, Mcl-1 levels diminish gradually, leading to the release of Bax and to its later 
translocation to the mitochondrial membrane (200). The amount of Mcl-1 can be regulated at the transcriptional level through NF- $\kappa \mathrm{B}$ and PI3K (201). Another mechanism of regulation of the neutrophil mitochondrial integrity is the flow of potassium (K). A high concentration of extracellular $\mathrm{K}^{+}$promotes the survival of neutrophils through the prevention of mitochondrial dysfunction and the release of proapoptotic factors.

\section{MODULATION OF CELL DEATH BY EXTRACELLULAR STIMULI}

Trans endothelial migration (exiting the blood vessel to reach the inflammation site) is one of the situations that promote neutrophil survival. At the inflammation site, neutrophils encounter various cytokines and chemokines that promote their activation and survival. Inflammatory mediators delay the spontaneous apoptosis of neutrophils, contributing to the persistence of inflammation. The mechanisms responsible for this delay, and for their increased resistance to apoptosis induced by anti-Fas antibodies, are related to the inhibition of caspase activity (202). Interferons type I and II delay neutrophil death through the activation of STAT3 and the positive regulation of the expression of the inhibitor of apoptosis protein 2 (cIAP) (203).

TLRs ligands, such as LPS, R-848, and CpG, delay spontaneous neutrophil apoptosis through the activation of Toll-like receptors (TLRs). Delay of neutrophil cell death is associated with greater phosphorylation of Akt and an increase in the levels of the antiapoptotic proteins Mcl-1 and A1 (204). Stimulation with LPS also regulates the decreased expression of many other factors related to apoptosis, suggesting that gene regulation can play an essential role in the modulation of neutrophil death (205). The lifespan of neutrophils can be also prolonged by G-CSF and GMCSF. GM-CSF can up regulate via PI3K/Akt the expression of antiapoptotic molecules, and down regulate the expression of proapoptotic molecules (206-208).

G-CSF can act by blocking Bid/Bax (195) and inhibiting the activation of caspase-3 (209). In a similar fashion, Bruno et al. (210) demonstrated in in-vitro experiments that the activation of the leptin receptors expressed on the membrane of neutrophils delayed their apoptosis. In addition, it was reported that high concentration of extracellular $\mathrm{K}+$ ions prevents $\mathrm{K}+$ efflux and delays neutrophil's apoptosis, suggesting that potassium released from damaged cells can function as a survival signal (211). Neutrophil death can also be delayed by activated endothelial cells through the release of GM-CSF and/or by direct interaction $(212,213)$. Similarly, neutrophil death is delayed by the interaction with natural killer (NK) cells, through the secretion of IFN- $\gamma$ and GM-CSF by the latter cells (214). These studies showed that neutrophil death can be delayed by their interaction with other cells, not only by the action of secreted cytokines, but also as a consequence of integrin signaling induced by direct cell-cell interaction (215).

Another molecule with an antiapoptotic function on neutrophils is the plasminogen activator inhibitor-1 (PAI-1), which is present in severe inflammatory states and is associated with neutrophil activation. PAI-1 activates antiapoptoticsignaling pathways, including the positive regulation of PKB/Akt, Mcl-1, and Bcl-x (L) (216). On the other hand, TNF- $\alpha$ plays a dual role in neutrophils: it can induce either their survival or death, and the effect is dependent on the intracellular, as well as on the extracellular environment (201). Survival tends to be favored at low doses of TNF- $\alpha$, while proapoptotic effects are observed at high concentrations (217-219).

Induction of cell death induced by TNF- $\alpha$ is mediated through its receptors by the activation of the JNK/MAPK pathways, release of ROS, and activation of caspase-8. However, cell death in the neutrophil can be caspase-independent (220). The TNF$\alpha$ receptors can also promote survival in human neutrophils, inhibiting spontaneous death by inducing an increase in PKC $\delta$ and PI3K activity (221) and promoting the expression of the antiapoptotic molecules $\mathrm{Al}$ and Bcl-XL through an NF-кBdependent pathway $(222,223)$.

\section{CELL DEATH RECEPTORS}

Apoptosis can be initiated by extracellular signals received through distinct membrane receptors known as death receptors or extrinsic pathway receptors. Two families of receptors have been identified as death receptors: the Fas protein (also called CD95 or APO-1) and receptors for TNF- $\alpha$.

The transmembrane Fas protein has an intracellular death domain that, when Fas is aggregated, interacts with the adaptor protein FADD (Fas-associated protein with death domain), which participates in cell death activating caspases 8 and 10 (224). Additionally, the intracellular domain of Fas can activate another factor called DAP6 (death domain-associated protein 6, or Daxx). DAP6 activates a protein kinase pathway leading to the opposite effect, stimulating entering into the cell cycle and mitosis (225).

The Fas pathway remains inactive until the extracellular domain binds to Fas ligand (Fas L), a protein expressed on the membrane of a neighbor cell that initiates the apoptosis pathway in the cells expressing Fas. Since this apoptotic pathway does not require de novo protein synthesis, it acts very fast inducing apoptosis.

The membrane receptor 1 for TNF (TNFR1) is a member of the TNF receptors superfamily that has in its intracellular portion a death domain, thus being capable of inducing cell death. Upon activation, its intracellular domain interacts with proteins such as TRADD (TNF receptor associated death domain) and RAIDD (226) (receptor associated interleukin death domain), which activate the caspases that can initiate apoptosis (227). However, it can also associate with a different factor denominated TRAF (TNF receptor associated factor), which activates protein-kinases and stimulates cell proliferation instead of apoptosis (228).

Neutrophils constitutively express high levels of Fas and Fas L on their membrane; thus, they are highly susceptible to cell death. The activation of Fas leads to an increase in the activation of caspases 8 and 3, and increases mitochondrial permeability (229). Fas signaling also increases mitochondrial permeability through Bid, Bak, and Bax, accelerating the apoptosis of neutrophils, but they are not necessary for apoptosis to be produced. Apoptosis 
triggered by Fas can be inhibited by Mcl-1 and Bcl-2 (230). The use of mitochondrial stabilizers significantly suppresses Fasmediated cell death, suggesting that mitochondrial alteration is an essential step for neutrophil apoptosis induced by Fas (229). Nonetheless, despite the large body of data showing that activation of the Fas/FasL pathway accelerates the death of neutrophils, there are studies conducted in Fas (lpr)- or FasL (gld)-deficient mice that show that the deficiency of either of these molecules does not alter the rate of neutrophil death. This suggests that FasL/Fas-mediated apoptosis is not essential in determining the lifespan of neutrophils during an acute inflammatory response $(231,232)$. In agreement with this, the blockage of Fas/FasL with specific antagonists did not alter the rate of spontaneous death of neutrophils (233).

Neutrophils also express other receptors, such as TRAIL-R2 and R3 and its ligand, the TNF-related apoptosis inducing ligand (TRAIL) $(234,235)$. It has been demonstrated that the exposure of neutrophils to exogenous TRAIL accelerates the process of cell death and it has been suggested that this ligand suppresses cytokines with antiapoptotic effects (236-239).

In Figure 1 we summarize the various pathways by which the neutrophil detects external signals through its PRRs and triggers effector functions, in addition to the activation of the different types of programmed cell death and the main signaling molecules involved.

\section{NEUTROPHILS DEATH AND DISEASE}

Neutrophil cell death has been found to participate in the pathophysiology of various diseases. The elucidation of the mechanisms involved is important to design prophylactic or therapeutic strategies to help patients. Given that great numbers of neutrophils are released daily to the circulation, a precise regulation of neutrophil death is essential to maintain the homeostatic equilibrium in the body. Neutrophils are of great importance in pathogen elimination due to their powerful antimicrobial arsenal. However, many of these microbicidal molecules can also enhance inflammation and tissue injury and can be detrimental for several inflammatory diseases.

\section{Clinical Implications With Apoptosis and Netosis Apoptosis}

In a normal inflammatory process, the apoptotic cells are recognized and removed by macrophages through efferocytosis, so that the inflammation process is regulated. Thus, it is important for neutrophils to undergo spontaneous apoptosis to contribute to the normal resolution of infections or inflammation. Conditions that delay or prevent neutrophil apoptosis result in neutrophilia and this can be a major contributor to chronicity. Gray et al. observed this phenomenon in cystic fibrosis patients, but a similar situation has been seen in many clinical conditions, especially in patients with lung diseases, such as lung cancer $(240,241)$, asthma $(242,243)$, chronic obstructive pulmonary disease (COPD) $(244,245)$, among others. Additionally, the extent of neutrophil apoptosis was found to be inversely proportional to the severity of sepsis in acute respiratory distress syndrome (ARDS). The mean percentage of apoptosis was significantly lower in sepsis-induced ARDS patients compared with uncomplicated sepsis (246).

A delay in neutrophil apoptosis has also been seen in inflammatory bowel disease (IBD) and the induction of apoptosis by the activation of different signaling pathways seems to be a possible solution for this disease. Zhang et al. observed that, in patients with IBD, treatment with TNF- $\alpha$ mAbs induces neutrophil apoptosis leading the resolution of inflammation in the intestinal mucosa (247). In a different study, Rossi et al. induced apoptosis of neutrophils using CDK inhibitors (that induce caspase dependent apoptosis) and found this facilitated the resolution of established neutrophil-dependent inflammation, suggesting this approach could be used to aid in the treatment of chronic inflammatory diseases (248).

On the other hand, a potentiated apoptosis could result in neutropenia and there are many pathological conditions related to this. Neutropenia is primarily associated with severe systemic bacterial infection. However, neutropenia due to excessive apoptosis can be found in systemic lupus erythematosus patients (249), patients undergoing hemodialysis (where apoptosis is related to the deficient biocompatibility of hemodialysis systems) (250), and congenital pathologies, such as myelokathexis, in which myeloid progenitors undergo spontaneous apoptosis due to the down regulated expression of $b c l-x$, an important regulator of apoptosis in hematopoietic cells (251).

\section{NETosis}

At the end of last century, the discovery of NETosis and its ability to kill bacteria gave rise to a whole new area of research. As the study of this phenomena advanced, it became evident that even though NETs are important effectors in the clearing of bacterial infections, they can also cause tissue injury (252-254). The precise regulation of NET release and the ensuing NETosis, the same as other cell death forms, is essential for maintaining the homeostatic equilibrium in the body. As mentioned before, a large array of factors that can cause inflammation are released during NETosis. Histones, e.g., are able to directly bind and activate platelets, accelerating thrombin production in a mechanism that is mediated by TLR 2 and TLR4 $(255,256)$. In 2007, it was demonstrated in an experimental model of sepsis that TLR4-dependent platelet-neutrophil interactions induced NET formation and that NETs are able to trap circulating E. coli, but at the expense of injury to the endothelium and tissue (257).

NETosis has been shown to be involved in many inflammatory processes and diseases ranging from systemic lupus erythematosus (258) to the new COVID-19. Neutrophils increase dramatically in COVID-19 and ARDS: cytokines that induce NETosis are present in patients' lungs and serum during SARS-CoV-2 infection (259-261). In addition, it has been suggested that NETs could be used as a severity marker in COVID-19 (262).

Previous reports have correlated NETs with pulmonary diseases, particularly ARDS. It has been seen that NETs, and in particular certain components like histones, are present in much higher levels in ARDS than in healthy controls, potentiating the 


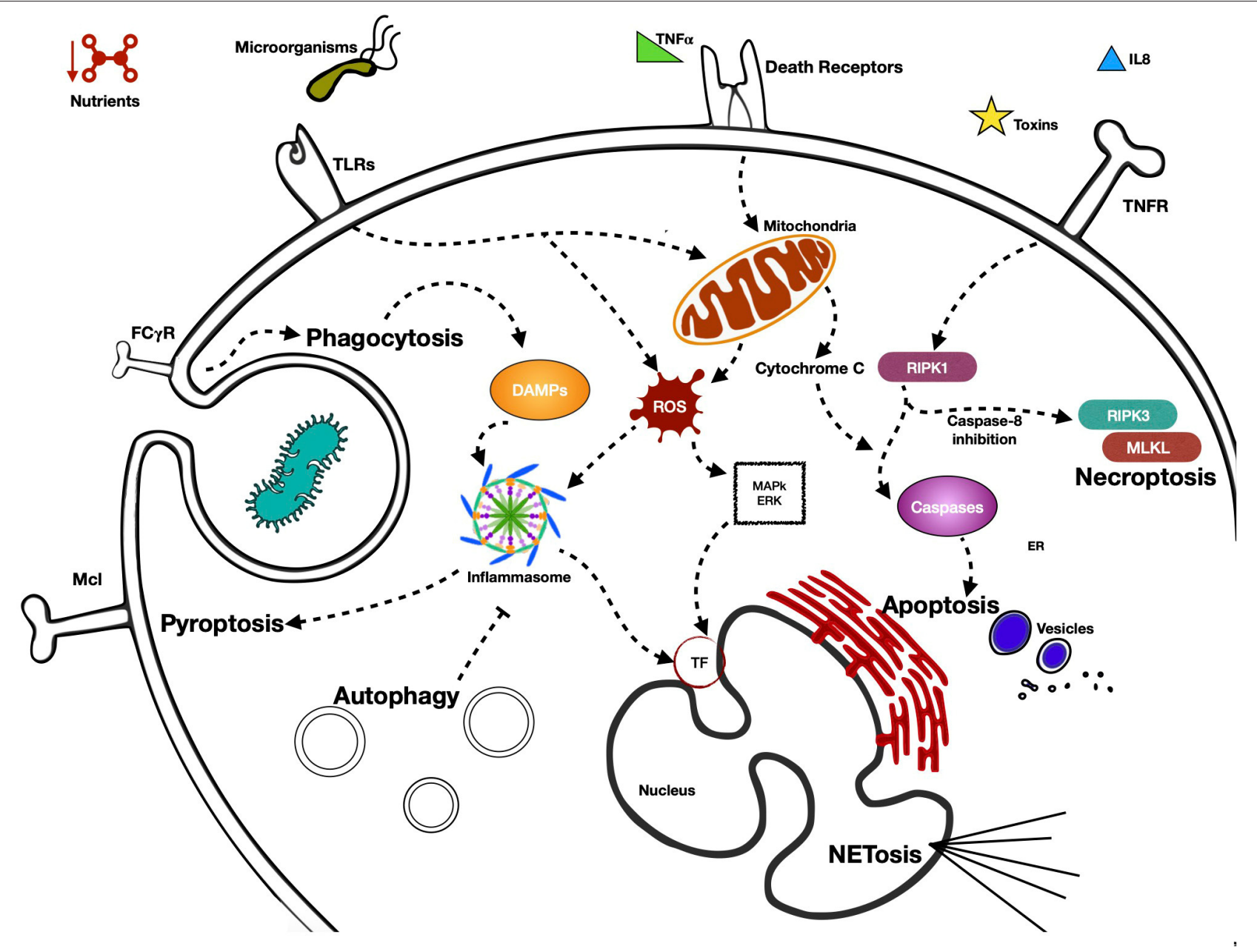

FIGURE 1 | Activation of different type of programmed cell neutrophil death, pathways by neutrophil senses external signals through its PRRs, and triggers effector functions. Neutrophils present in their cellular membrane, a great variety of receptors (pattern recognition receptors, PRR) that are capable of sensoring diverse MAMP (microorganisms associated molecular patterns) and DAMPs (damage-associated molecular patterns). Depending on the nature and intensity of the stimulus received, PRRs are capable of initiating signaling cascades that generally terminate in processes of cell death. These are mainly initiated by proinflammatory proteins, which possess effector functions that lead to the death of neutrophils by means of different mechanisms, such as NETosis, autophagy, necroptosis, or pyroptosis, among others. The receptor that is activated in the processes of cell death is very important, defining as it does the form of cell death that the cell takes. The processes of cell death generally begin with the receptor itself. However, the signaling cascade defines at some point what the fate of the neutrophil will be.

severity of the syndrome and patient's mortality (263-266). In addition, NETs from excessive NETosis makes mucus thicker and more viscous, facilitating bacterial infection, which in turn recruits more neutrophils and promotes further production of NETs. Consequently, the respiratory function of patients is progressively affected, increasing the severity of the disease (267).

NETs release by activated neutrophils in circulation can promote thrombosis in veins and arteries $(268,269)$. It has been shown in thrombosis animal models that coagulation may be enhanced by direct NET-dependent activation of the contact system $(256,270)$.

Moreover, a correlation has been demonstrated between NETs production and IL- $1 \beta$ and IL-6, associated with a proinflammatory state $(271,272)$ and the relationship between NETs and permanent organ damage in the cardiovascular and renal systems is well-known $(273,274)$. The potential of NETs to induce tissue damage underlines the importance of considering NETs evaluation in severe COVID-19 patients, it and suggests that targeting NETs may lessen the severe multi-organ consequences of COVID-19 (275).

\section{Clinical Implications of Other Types of Neutrophil Death}

Apoptosis and NETosis are very important neutrophil death forms in disease. Apoptosis due to the homeostatic regulation that must be accomplished in the body and its relation to neutrophils activity, and NETosis due to its ability to enhance inflammation, contributing to the pathophysiology of several diseases. The contribution of these two types of neutrophil death 
TABLE 1 | Receptors involved in distinct mechanisms of cell death of neutrophils.

\begin{tabular}{|c|c|c|c|c|}
\hline Apoptosis & Necroptosis & NETosis & Autophagy & Phagocytosis \\
\hline TNFR $(201,219)$ & Death receptors: & FPR1/2 & TLR & $\mathrm{FC} \gamma \mathrm{R}$ \\
\hline FAS (APO-1/CD95) (232) & TNFR & FCgR (283) & NOD & \\
\hline DR3 (APO-3/TRAMP) (201) & TLR & nAChR (284) & NLR & \\
\hline DR4 (TRAIL-R1) (236) & INFAR & CR3 (285) & CLR & \\
\hline DR5 (TRAIL-R2(236) & & $\begin{array}{l}\text { C5aR (when IFN- } \beta \text { is used } \\
\text { as a priming cytokine) (286) }\end{array}$ & & \\
\hline \multirow[t]{4}{*}{ DR6 (201) } & Adhesion receptors: & & & \\
\hline & CD11b & & & \\
\hline & CD15 & & & \\
\hline & CD18 (62) & & & \\
\hline
\end{tabular}

TABLE 2 | Sensor proteins and signal cell death in distinct mechanisms of cell death of neutrophils.

\begin{tabular}{|c|c|c|c|c|}
\hline Apoptosis & Necrosis & Necroptosis & Pyroptosis & NETosis \\
\hline Caspase-2,-3,-6,-7,-8,-9,-10 & $\mathrm{HIF}$ & RIPK1 & Caspase $-1,-11$ & Platelet-neutrophil interaction \\
\hline Mitochondrial $\left[\mathrm{Ca}^{2+}\right]$ uptake & Nutrients & RIPK3 & Inflammasome & \\
\hline PIDDosome & Temperature & MLKL & & \\
\hline \multirow[t]{2}{*}{ Cythocrome C, ROS } & Mechanical stress & NADPH oxidase (via NETosis) & & \\
\hline & Bacteria & & & \\
\hline
\end{tabular}

to disease has received much attention, although other types of neutrophil cell death can also contribute to disease.

Autophagy could participate in disease in a similar way to apoptosis, since enhanced autophagy can result in neutropenia. Olcay et al. showed marked autophagy in neutrophils of patients with congenital dysgranulopoietic neutropenia (CDN), although it cannot be proved that the excess of autophagy may have caused the neutropenia (276).

Neutrophils are the first line of cellular protection against infection, so many of the clinical problems related to dysregulation of their programed cell death is reflected in relation to infection/sepsis diseases.

Pyroptosis is essentially a form of programmed cell death caused by intracellular pathogen infection. Although neutrophils are especially resistant to pyroptosis, it has been demonstrated that they can undergo this form of programmed cell death when there is an absence of a functional NADPH oxidase Nox2 during acute lung infection with $P$. aeruginosa (123), probably to compensate the absence of an antimicrobial pathway. Since neutrophils play an important role in sepsis, it has been suggested that the regulation of neutrophil pyroptosis may positively impact sepsis treatment (277).

Necrosis is usually considered a more pathological form of cell death. When neutrophils die by necrosis, their cytoplasmatic content may cause additional tissue damage or inflammation and it could promote chronic inflammation rather than the resolution of the problem $(278,279)$. Most of the clinically detrimental effects related to neutrophil necrosis are caused by the virulence of bacteria. This is the case of patients with chronic granulomatous disease, whose neutrophils undergo necrosis after Burkholderia cenocepacia infection (280) or the
Haemophilus influenzae infection, commonly found in patients with COPD (281).

There are some studies that have related chronic inflammation to programmed neutrophil necrosis (282), but there is not much research about pathologies resulting specifically from neutrophil necroptosis. The most known cell types that are correlated with necroptosis-diseases in humans are epithelial liver (270), intestine, and skin cells (68). It was recently found that in patients with neutrophilic diseases, including cutaneous vasculitis, ulcerative colitis, and psoriasis, the migration of neutrophils to infection sites can trigger necroptosis through different adhesion molecules (76).

\section{CONCLUSION}

The humoral and cellular components of the innate and acquired immune response form a host-defense integrated system, in which numerous cells and molecules function collectively. Cells of the innate immune response are not only effector cells that can attack the invading microbe immediately, but they also influence the type of specific adaptive response that is subsequently developed. In this regard, neutrophils are very important participants in the immunological response. This is not only because they are important effector cells with great microbicidal activity, but also for the role their products play in the initiation of an adaptive immune response. Since the lifespan of neutrophils is short due to a constitutive program for apoptosis, cytokines and other stimuli at inflammatory sites can delay this apoptosis program. On the other hand, once the pathogenic threat is eliminated, neutrophil death and their 
subsequent clearance by macrophages is extremely important for the resolution of inflammation. Dysregulation of the rate of neutrophils death can have deleterious effects. Accelerated death or neutrophils can lead to inefficient pathogen clearance, but delays in their death can result in exacerbated tissue damage and chronic inflammation. Thus, the study of the mechanisms regulating neutrophil death and survival, both in homeostasis and in inflammatory states, is of great interest.

It is noteworthy that all the mechanisms that trigger the death of neutrophils are important to provide signals that contribute to the initiation of an adaptive response, as well as to the recovery of the homeostasis of the tissue and the organism, which are also possible targets of inflammatory diseases (Tables 1, 2). A better understanding of the mechanisms underlying the cell death of neutrophils will aid in understanding their physiology and will contribute in the search for novel approaches for the management of pathologies such as, cystic fibrosis, asthma, COPD, ARDS, sepsis, IBD, systemic lupus erythematosus, myelokathexis, COVID-19, thrombosis,

\section{REFERENCES}

1. Kantari C, Pederzoli-Ribeil M, Witko-Sarsat V. The role of neutrophils and monocytes in innate immunity. Contrib Microbiol. (2008) 15:118-46. doi: $10.1159 / 000136335$

2. Cascão R, Rosário HS, Souto-Carneiro MM, Fonseca JE. Neutrophils in rheumatoid arthritis: more than simple final effectors. Autoimmun Rev. (2010) 9:531-5. doi: 10.1016/j.autrev.2009.12.013

3. Kuijpers TW, Hakkert BC, Hart MHL, Roos D. Neutrophil migration across monolayers of cytokine-prestimulated endothelial cells: a role for platelet-activating factor and IL-8. J Cell Biol. (1992) 117:565-72. doi: $10.1083 /$ jcb.117.3.565

4. Borregaard N, Theilgaard-Mönch K, Cowland JB, Ståhle M, Sørensen OE. Neutrophils and keratinocytes in innate immunity-cooperative actions to provide antimicrobial defense at the right time and place. J Leukoc Biol. (2005) 0.77:439-43. doi: 10.1189/jlb.0704381

5. Soehnlein O, Lindbom L. Phagocyte partnership during the onset and resolution of inflammation. Nat Rev Immunol. (2010) 10:427-39. doi: $10.1038 /$ nri2779

6. Groselj-Grenc M, Ihan A, Derganc M. Neutrophil and monocyte CD64 and CD163 expression in critically Ill neonates and children with sepsis: comparison of fluorescence intensities and calculated indexes. Mediators Inflamm. (2008) 2008:1-10. doi: 10.1155/2008/202646

7. Futosi K, Fodor S, Mócsai A. Neutrophil cell surface receptors and their intracellular signal transduction pathways. Int Immunopharmacol. (2013) 17:638-50. doi: 10.1016/j.intimp.2013.06.034

8. Czop JK, Puglisi AV, Miorandi DZ, Austen KF. Perturbation of $\beta$-glucan receptors on human neutrophils initiates phagocytosis and leukotriene B4 production. J Immunol. (1998) 141:3170-6.

9. Taylor PR, Brown GD, Reid DM, Willment JA, Martinez-Pomares L, Gordon $\mathrm{S}$, et al. The $\beta$-glucan receptor, dectin-1, is predominantly expressed on the surface of cells of the monocyte/macrophage and neutrophil lineages. $J$ Immunol. (2002) 169:3876-82. doi: 10.4049/jimmunol.169.7.3876

10. Haziot A, Tsuberi BZ, Goyert SM. Neutrophil CD14: Biochemical properties and role in the secretion of tumor necrosis factor- $\alpha$ in response to lipopolysaccharide. J Immunol. (1993) 0.150:5556-5565.

11. Antal-Szalmas P, Strijp JA, Weersink AJ, Verhoef J, Van Kessel KP. Quantitation of surface CD14 on human monocytes and neutrophils. $J$ Leukoc Biol. (1997) 61:721-8. doi: 10.1002/jlb.61.6.721

12. Leigh LE, Ghebrehiwet B, Perera TP, Bird IN, Strong P, Kishore U, et al. C1q-mediated chemotaxis by human neutrophils: involvement of cutaneous vasculitis, ulcerative colitis, and psoriasis, all of them related with alterations in the death mechanisms of these cells. It will also increase our understanding of inflammation in general, allowing us to identify new factors, molecules, and mechanisms that could have possible medical applications. Therefore, their study and their effects are maintained as a broad field of research.

\section{AUTHOR CONTRIBUTIONS}

EP-F and PÁ-C reviewed the literature and prepared drafts of the manuscript. EO and CM-B assisted in evaluation of the literature and finalizing manuscript for submission. All authors contributed to the article and approved the submitted version.

\section{FUNDING}

This work was supported by Hospital Infantil de México Federico Gómez, Grant HIM/2017/129.
gClqR and G-protein signalling mechanisms. Biochem J. (1998) 330:247-54. doi: $10.1042 /$ bj3300247

13. Zhou MJ, Lublin DM, Link DC, Brown EJ. Distinct tyrosine kinase activation and triton X-100 insolubility upon Fc $\gamma$ RII or Fc $\gamma$ RIIIB ligation in human polymorphonuclear leukocytes: Implications for immune complex activation of the respiratory burst. J Biol Chem. (1995) 270:13553-60. doi: 10.1074/jbc.270.22.13553

14. Coxon A, Cullere X, Knight S, Sethi S, Wakelin MW, Stavrakis $\mathrm{G}$, et al. Fc $\gamma$ RIII mediates neutrophil recruitment to immune complexes: a mechanism for neutrophil accumulation in immune-mediated inflammation. Immunity. (2001) 14:693-704. doi: 10.1016/S1074-7613(01)00150-9

15. Selvaraj P, Fifadara N, Nagarajan S, Cimino A, Wang G. Functional regulation of human neutrophil Fc $\gamma$ receptors. Immunol Res. (2004) 29:21930. doi: 10.1385/IR:29:1-3:219

16. Jakus Z, Németh T, Verbeek JS, Mócsai A. Critical but overlapping role of $f(\gamma$ riii and fcyriv in activation of murine neutrophils by immobilized immune complexes. J Immunol. (2008) 180:618-29. doi: 10.4049/jimmunol.180.1.618

17. van Bruggen R, Drewniak A, Jansen M, van Houdt M, Roos D, Chapel H, et al. Complement receptor 3, not Dectin-1, is the major receptor on human neutrophils for $\beta$-glucan-bearing particles. Mol Immunol. (2009) 47:75-81. doi: 10.1016/j.molimm.2009.09.018

18. Weckbach LT, Gola A, Winkelmann M, Jakob SM, Groesser L, Borgolte J, et al. The cytokine midkine supports neutrophil trafficking during acute inflammation by promoting adhesion via $\beta 2$ integrins (CD11/CD18). Blood. (2014) 123:1887-96. doi: 10.1182/blood-2013-06-510875

19. Greenlee-Wacker MC. Clearance of apoptotic neutrophils and resolution of inflammation. Immunol Rev. (2016) 273:357-70. doi: 10.1111/imr.12453

20. Hayashi F, Means TK, Luster AD. Toll-like receptors stimulate human neutrophil function. Blood. (2003) 102:2660-9. doi: 10.1182/blood-2003-04-1078

21. Ekman AK, Cardell LO. The expression and function of Nodlike receptors in neutrophils. Immunology. (2010) 130:55-63. doi: 10.1111/j.1365-2567.2009.03212.x

22. Break TJ, Jun S, Indramohan M, Carr KD, Sieve AN, Berg RE. Extracellular superoxide dismutase inhibits innate immune responses and clearance of an intracellular bacterial infection. J Immunol. (2012) 188:3342-50. doi: 10.4049/jimmunol.1102341

23. Savil JS, Wyllie AH, Henson JE, Walport MJ, Henson PM, Haslett C. Macrophage phagocytosis of aging neutrophils in inflammation. 
Programmed cell death in the neutrophil leads to its recognition by macrophages. J Clin Invest. (1989) 83:865-75. doi: 10.1172/JCI113970

24. Haslett C, Savill JS, Whyte MK, Stern M, Dransfield I, Meagher LC. Granulocyte apoptosis and the control of inflammation. Philos Trans R Soc Lond B Biol Sci. (1994) 345:327-33. doi: 10.1098/rstb.1994.0113

25. Maianski NA, Maianski AN, Kuijpers TW, Roos D. Apoptosis of neutrophils. Acta Haematol. (2004) 111:56-66. doi: 10.1159/000074486

26. Stock W, Hoffman R. White blood cells 1: non-malignant disorders. Lancet. (2000) 355:1351-57. doi: 10.1016/S0140-6736(00)02125-5

27. Andrès E, Maloisel F. Idiosyncratic drug-induced agranulocytosis or acute neutropenia. Curr Opin Hematol. (2008) 15:15-21. doi: 10.1097/MOH.0b013e3282f15fb9

28. Akgul C, Moulding DA, Edwards SW. Molecular control of neutrophil apoptosis. FEBS Lett. (2001) 487:318-22. doi: 10.1016/S0014-5793(00)02324-3

29. Scheel-Toellner D, Wang K, Assi LK, Webb PR, Craddock RM, Salmon M, et al. Clustering of death receptors in lipid rafts initiates neutrophil spontaneous apoptosis. Biochem Soc Trans. (2004) 32:679-81. doi: 10.1042/BST0320679

30. Krysko DV, Vanden Berghe T, D'Herde K, Vandenabeele P. Apoptosis and necrosis: detection, discrimination and phagocytosis. Methods. (2008) 44:205-21. doi: 10.1016/j.ymeth.2007.12.001

31. Krysko DV, Vanden Berghe T, Parthoens E, D’Herde K, Vandenabeele P. Methods for distinguishing apoptotic from necrotic cells and measuring their clearance. Methods Enzymol. (2008) 442:307-41. doi: 10.1016/S0076-6879(08)01416-X

32. Geering B, Simon HU. Peculiarities of cell death mechanisms in neutrophils. Cell Death Differ. (2011) 18:1457-69. doi: 10.1038/cdd.2011.75

33. Gabelloni ML, Trevani AS, Sabatté J, Geffner J. Mechanisms regulating neutrophil survival and cell death. Semin Immunopathol. (2013) 35:423-37. doi: 10.1007/s00281-013-0364-x

34. Whyte MK, Meagher LC, Macdermot J, Haslett C. Impairment of function in aging neutrophils is impairment of function in aging neutrophils is associated with apoptosis. J Immunol. (1993) 150:5124-5134.

35. Serhan CN, Savill J. Resolution of inflammation: the beginning programs the end. Nat Immunol. (2005) 6:1191-7. doi: 10.1038/ni1276

36. Dransfield I, Stocks S, Haslett C. Regulation of cell adhesion molecule expression and function associated with neutrophil apoptosis. Blood. (1995) 85:3264-73. doi: 10.1182/blood.V85.11.3264.bloodjournal85113264

37. Jones J, Morgan BP. Apoptosis is associated with reduced expression of complement regulatory molecules, adhesion molecules and other receptors on polymorphonuclear leucocytes: functional relevance and role in inflammation. Immunology. (1995) 86:651-60.

38. Ayub K, Hallett MB. Ca2+ influx shutdown during neutrophil apoptosis: importance and possible mechanism. Immunology. (2004) 111:8-12. doi: 10.1111/j.1365-2567.2004.01766.x

39. Yamamoto A, Taniuchi S, Tsuji S, Hasui M, Kobayashi Y. Role of reactive oxygen species in neutrophil apoptosis following ingestion of heat-killed Staphylococcus aureus. Clin Exp Immunol. (2002) 129:479-84. doi: 10.1046/j.1365-2249.2002.01930.x

40. Medan D, Wang L, Yang X, Dokka S, Castranova V, Rojanasakul Y. Induction of neutrophil apoptosis and secondary necrosis during endotoxininduced pulmonary inflammation in mice. J Cell Physiol. (2002) 191:320-6. doi: $10.1002 / j c p .10105$

41. Scannell M, Flanagan MB, DeStefani A, Wynne KJ, Cagney G, Godson C, et al. Annexin-1 and peptide derivatives are released by apoptotic cells and stimulate phagocytosis of apoptotic neutrophils by macrophages. J Immunol. (2007) 178:4595-605. doi: 10.4049/jimmunol.178.7.4595

42. Michlewska S, Dransfield I, Megson IL, Rossi AG. Macrophage phagocytosis of apoptotic neutrophils is critically regulated by the opposing actions of proinflammatory and anti-inflammatory agents: key role for TNF-alpha. FASEB J. (2009) 23:844-54. doi: 10.1096/fj.08-121228

43. Colotta F, Re F, Polentarutti N, Sozzani S, Mantovani A. Modulation of granulocyte survival and programmed cell death by cytokines and bacterial products. Blood. (1992) 80:2012-20. doi: 10.1182/blood.V80.8.2012.2012

44. Lee A, Whyte MK, Haslett C. Inhibition of apoptosis and prolongation of neutrophil functional longevity by inflammatory mediators. J Leukoc Biol. (1993) 54:283-8. doi: 10.1002/jlb.54.4.283
45. Kobayashi Y. The role of chemokines in neutrophil biology. Front Biosci. (2008) 13:2400-7. doi: 10.2741/2853

46. Simon HU. Neutrophil apoptosis pathways and their modifications in inflammation. Immunol Rev. (2003) 193:101-10. doi: 10.1034/j.1600-065X.2003.00038.x

47. Hu Z, Sayeed MM. Activation of PI3-kinase/PKB contributes to delay in neutrophil apoptosis after thermal injury. Am J Physiol Cell Physiol. (2005) 5:C1171-8. doi: 10.1152/ajpcell.00312.2004

48. Andina N, Conus S, Schneider EM, Fey MF, Simon HU. Induction of Bim limits cytokine-mediated prolonged survival of neutrophils. Cell Death Differ. (2009) 16:1248-55. doi: 10.1038/cdd.2009.50

49. Kettritz R, Xu YX, Kerren T, Quass P, Klein JB, Luft FC, et al. Extracellular matrix regulates apoptosis in human neutrophils. Kidney Int. (1999) 55:56271. doi: 10.1046/j.1523-1755.1999.00280.x

50. Ward-Kavanagh LK, Lin WW, Šedý JR, Ware CF. The TNF receptor superfamily in co-stimulating and co-inhibitory responses. Immunity. (2016) 44:1005-19. doi: 10.1016/j.immuni.2016.04.019

51. Beyer K, Baukloh AK, Stoyanova A, Kamphues C, Sattler A, Kotsch K. Interactions of tumor necrosis factor-related apoptosis-inducing ligand (TRAIL) with the immune system: implications for inflammation and cancer. Cancers. (2019) 11:1161. doi: 10.3390/cancers11081161

52. Sengeløv H, Nielsen MH, Borregaard N. Separation of human neutrophil plasma membrane from intracellular vesicles containing alkaline phosphatase and NADPH oxidase activity by free flow electrophoresis. J Biol Chem. (1992) 267:14912-7. doi: 10.1016/S0021-9258(18)42127-8

53. Simon HU, Haj-Yehia A, Levi-Schaffer F. Role of reactive oxygen species (ROS) in apoptosis induction. Apoptosis. (2000) 5:415-8. doi: 10.1023/A:1009616228304

54. Makni-Maalej K, Marzaioli V, Boussetta T, Belambri SA, Gougerot-Pocidalo MA, Hurtado-Nedelec M, et al. TLR8, but not TLR7, induces the priming of the NADPH oxidase activation in human neutrophils. J Leukoc Biol. (2015) 97:1081-7. doi: 10.1189/jlb.2A1214-623R

55. Buck A, Sanchez Klose FP, Venkatakrishnan V, Khamzeh A, Dahlgren C, Christenson K, et al. DPI Selectively Inhibits Intracellular NADPH Oxidase Activity in Human Neutrophils. Immunohorizons. (2019) 3:488-97. doi: 10.4049/immunohorizons. 1900062

56. Douda DN, Yip L, Khan MA, Grasemann H, Palaniyar N. Akt is essential to induce NADPH-dependent NETosis and to switch the neutrophil death to apoptosis. Blood. (2014) 123:597-600. doi: 10.1182/blood-2013-09-526707

57. Khan MA, Farahvash A, Douda DN, Licht JC, Grasemann H, Sweezey $\mathrm{N}$, et al. JNK Activation Turns on LPS- and gram-negative bacteriainduced nadph oxidase-dependent suicidal netosis. Sci Rep. (2017) 7:3409. doi: 10.1038/s41598-017-03257-z

58. Nadesalingam A, Chen JHK, Farahvash A, Khan MA. Hypertonic saline suppresses NADPH oxidase-dependent neutrophil extracellular trap formation and promotes apoptosis. Front Immunol. (2018) 9:359. doi: 10.3389/fimmu.2018.00359

59. Azzouz D, Khan MA, Sweezey N, Palaniyar N. Two-in-one: UV radiation simultaneously induces apoptosis and NETosis. Cell Death Discov. 4:51. doi: 10.1038/s41420-018-0048-3

60. Zhang DW, Shao J, Lin J, Zhang N, Lu BJ, Lin SC, et al. RIP3, an energy metabolism regulator that switches TNF-induced cell death from apoptosis to necrosis. Science. (2009) 325:332-6. doi: 10.1126/science. 1172308

61. He S, Wang L, Miao L, Wang T, Du F, Zhao L, et al. Receptor interacting protein kinase-3 determines cellular necrotic response to TNF- $\alpha$. Cell. (2009) 137:1100-11. doi: 10.1016/j.cell.2009.05.021

62. Wang X, He Z, Liu H, Yousefi S, Simon HU. Neutrophil necroptosis is triggered by ligation of adhesion molecules following GM-CSF priming. J Immunol. (2016) 197:4090-100. doi: 10.4049/jimmunol. 1600051

63. Kaiser WJ, Sridharan H, Huang C, Mandal P, Upton JW, Gough PJ, et al. Toll-like receptor 3-mediated necrosis via TRIF, RIP3, MLKL. J Biol Chem. (2013) 288:31268-79. doi: 10.1074/jbc.M113.462341

64. Thapa RJ, Nogusa S, Chen P, Maki JL, Lerro A, Andrake M, et al. Interferoninduced RIP1/RIP3-mediated necrosis requires PKR and is licensed by FADD and caspases. Proc Natl Acad Sci USA. (2013) 110:E3109-18. doi: $10.1073 /$ pnas. 1301218110 
65. Dillon CP, Weinlich R, Rodriguez DA, Cripps JG, Quarato G, Gurung P, et al. RIPK1 blocks early postnatal lethality mediated by caspase- 8 and RIPK3. Cell. (2014) 157:1189-202. doi: 10.1016/j.cell.2014.04.018

66. Benarafa C, Simon HU. Role of granule proteases in the life and death of neutrophils. Biochem Biophys Res Commun. (2017) 482:473-81. doi: 10.1016/j.bbrc.2016.11.086

67. Upton JW, Kaiser WJ, Mocarski ES. DAI/ZBP1/DLM-1 complexes with RIP3 to mediate virus-induced programmed necrosis that is targeted by murine cytomegalovirus vIRA. Cell Host Microbe. (2012) 11:290-7. doi: $10.1016 /$ j.chom.2012.01.016

68. Pasparakis M, Vandenabeele P. Necroptosis and its role in inflammation. Nature. (2015) 517:311-20. doi: 10.1038/nature14191

69. Feoktistova M, Geserick P, Kellert B, Dimitrova DP, Langlais C, Hupe M, et al. CIAPs block ripoptosome formation, a RIP1/Caspase-8 containing intracellular cell death complex differentially regulated by cflip isoforms. Mol Cell. (2011) 43:449-63. doi: 10.1016/j.molcel.2011.06.011

70. Moulin M, Anderton H, Voss AK, Thomas T, Wong WW, Bankovacki A, et al. IAPs limit activation of RIP kinases by TNF receptor 1 during development. EMBO J. (2012) 31:1679-91. doi: 10.1038/emboj. 2012.18

71. Wong WW, Vince JE, Lalaoui N, Lawlor KE, Chau D, Bankovacki A, et al. cIAPs and XIAP regulate myelopoiesis through cytokine production in an RIPK1- and RIPK3-dependent manner. Blood. (2014) 123:2562-72. doi: 10.1182/blood-2013-06-510743

72. Dondelinger Y, Jouan-Lanhouet S, Divert T, Theatre E, Bertin J, Gough PJ, et al. NF-KB-Independent role of IKK $\alpha /$ IKK $\beta$ in preventing RIPK1 kinasedependent apoptotic and necroptotic cell death during TNF signaling. Mol Cell. (2015) 60:63-76. doi: 10.1016/j.molcel.2015.07.032

73. Wang L, Du F, Wang X. TNF- $\alpha$ induces two distinct caspase- 8 activation pathways. Cell. (2008) 133:693-703. doi: 10.1016/j.cell.2008.03.036

74. Sun L, Wang H, Wang Z, He S, Chen S, Liao D, et al. Mixed lineage kinase domain-like protein mediates necrosis signaling downstream of RIP3 kinase. Cell. (2012) 148:213-27. doi: 10.1016/j.cell.2011.11.031

75. Zhao J, Jitkaew S, Cai Z, Choksi S, Li Q, Luo J, et al. Mixed lineage kinase domain-like is a key receptor interacting protein 3 downstream component of TNF-induced necrosis. Proc Natl Acad Sci USA. (2012) 109:5322-27. doi: 10.1073/pnas.1200012109

76. Wang X, Yousefi S, Simon H-U. Necroptosis and neutrophil-associated disorders. Cell Death Dis. (2018) 9:111. doi: 10.1038/s41419-017-0058-8

77. Desai J, Mulay SR, Nakazawa D, Anders HJ. Matters of life and death. How neutrophils die or survive along NET release and is "NETosis" = necroptosis? Cell Mol Life Sci. (2016) 73:2211-9. doi: 10.1007/s00018-016-2195-0

78. Golstein P, Kroemer G. Cell death by necrosis: towards a molecular definition. Trends Biochem Sci. (2007) 32:37-43. doi: 10.1016/j.tibs.2006.11.001

79. Vanden Berghe T, Vanlangenakker N, Parthoens E, Deckers W, Devos M, Festjens N, et al. Necroptosis, necrosis and secondary necrosis converge on similar cellular disintegration features. Cell Death Differ. (2010) 17:922-30. doi: $10.1038 /$ cdd.2009.184

80. Vakifahmetoglu-Norberg H, Ouchida AT, Norberg E. The role of mitochondria in metabolism and cell death. Biochem Biophys Res Commun. (2017) 482:426-31. doi: 10.1016/j.bbrc.2016.11.088

81. Li M, Carpio DF, Zheng Y, Bruzzo P, Singh V, Ouaaz F, et al. An essential role of the NF- B/toll-like receptor pathway in induction of inflammatory and tissue-repair gene expression by necrotic cells. J Immunol. (2001) 166:712835. doi: 10.4049/jimmunol.166.12.7128

82. Vanlangenakker N, Berghe T, Krysko D, Festjens N, Vandenabeele P. Molecular mechanisms and pathophysiology of necrotic cell death. Curr Mol Med. (2008) 8:207-20. doi: 10.2174/156652408784221306

83. Sobolewski A, Murray J, Bradley JR, Cadwallader KA, Reed BJ, Chilvers ERAminopeptidase $\mathrm{N}$ (CD13) regulates tumor necrosis factor- $\alpha$-induced apoptosis in human neutrophils. J Biol Chem. (2006) 281:12458-67. doi: 10.1074/jbc.M511277200

84. Brinkmann V, Reichard U, Goosmann C, Fauler B, Uhlemann Y, Weiss DS, et al. Neutrophil extracellular traps kill bacteria. Science. (2004) 303:1532-5. doi: $10.1126 /$ science. 1092385
85. Yousefi S, Simon D, Simon HU. Eosinophil extracellular DNA traps: molecular mechanisms and potential roles in disease. Curr Opin Immunol. (2012) 24:736-9. doi: 10.1016/j.coi.2012.08.010

86. Fuchs TA, Abed U, Goosmann C, Hurwitz R, Schulze I, Wahn V, et al. Novel cell death program leads to neutrophil extracellular traps. J Cell Biol. (2007) 176:231-41. doi: 10.1083/jcb.200606027

87. Zawrotniak M, Rapala-Kozik M. Neutrophil extracellular traps (NETs) formation and implications. Acta Biochim Pol. (2013) 60:277-84. doi: 10.18388/abp.2013_1983

88. Leupold S, Büsing P, Mas PJ, Hart DJ, Scrima A. Structural insights into the architecture of the Shigella flexneri virulence factor IcsA/VirG and motifs involved in polar distribution and secretion. J Struct Biol. (2017) 198:19-27. doi: $10.1016 /$ j.jsb.2017.03.003

89. Guichon A, Hersh D, Smith MR, Zychlinsky A. Structure-function analysis of the shigella virulence factor IpaB. J Bacteriol. (2001) 183:1269-76. doi: 10.1128/JB.183.4.1269-1276.2001

90. Averhoff P, Kolbe M, Zychlinsky A, Weinrauch Y. Single residue determines the specificity of neutrophil elastase for Shigella virulence factors. J Mol Biol. (2008) 377:1053-66. doi: 10.1016/j.jmb.2007.12.034

91. Kenny EF, Herzig A, Krüger R, Muth A, Mondal S, Thompson PR, et al. Diverse stimuli engage different neutrophil extracellular trap pathways. Elife. (2017) 6:1-21. doi: 10.7554/eLife.24437

92. Jorch SK, Kubes P. An emerging role for neutrophil extracellular traps in noninfectious disease. Nat Med. (2017) 23:279-87. doi: 10.1038/nm.4294

93. Remijsen Q, Vanden Berghe T, Wirawan E, Asselbergh B, Parthoens E, De Rycke R, et al. Neutrophil extracellular trap cell death requires both autophagy and superoxide generation. Cell Res. (2011) 21:290-304. doi: 10.1038/cr.2010.150

94. Asaga H, Senshu T, Ishigami A, Nakashima K, Yamada M. Immunocytochemical localization of peptidylarginine deiminase in human eosinophils and neutrophils. J Leukoc Biol. (2001) 70:46-51.

95. Zhou Y, An LL, Chaerkady R, Mittereder N, Clarke L, Cohen TS, et al. Evidence for a direct link between PAD4-mediated citrullination and the oxidative burst in human neutrophils. Sci Rep. (2018) 8:15228. doi: 10.1038/s41598-018-33385-z

96. Li RHL, Ng G, Tablin F. Lipopolysaccharide-induced neutrophil extracellular trap formation in canine neutrophils is dependent on histone $\mathrm{H} 3$ citrullination by peptidylarginine deiminase. Vet Immunol Immunopathol. (2017) 193-4:29-37. doi: 10.1016/j.vetimm.2017.10.002

97. Douda DN, Khan MA, Grasemann H, Palaniyar N. SK3 channel and mitochondrial ROS mediate NADPH oxidase-independent NETosis induced by calcium influx. Proc Natl Acad USA. (2015) 112:2817-22. doi: $10.1073 /$ pnas. 1414055112

98. Khan MA, D’Ovidio A, Tran H, Palaniyar N. Anthracyclines suppress both NADPH oxidase- dependent and -independent netosis in human Neutrophils. Cancers (Basel). (2019) 11:1328. doi: 10.3390/cancers11091328

99. Díaz-Godínez C, Carrero JC. The state of art of neutrophil extracellular traps in protozoan and helminthic infections. Biosci Rep. (2018) 39:BSR20180916. doi: 10.1042/BSR20180916

100. Papayannopoulos V, Metzler KD, Hakkim A, Zychlinsky A. Neutrophil elastase and myeloperoxidase regulate the formation of neutrophil extracellular traps. J Cell Biol. (2010) 191:677-91. doi: 10.1083/jcb.201006052

101. Urban CF, Ermert D, Schmid M, Abu-Abed U, Goosmann C, Nacken W, et al. Neutrophil extracellular traps contain calprotectin, a cytosolic protein complex involved in host defense against candida albicans. PLoS Pathog. (2009) 5:e1000639. doi: 10.1371/journal.ppat.1000639

102. Wilkie RP, Vissers MCM, Dragunow M, Hampton MB. A Functional NADPH oxidase prevents caspase involvement in the clearance of phagocytic neutrophils. Infect Immun. (2007) 75:3256-63. doi: 10.1128/IAI.01984-06

103. Hakkim A, Fuchs TA, Martinez NE, Hess S, Prinz H, Zychlinsky $A$, et al. Activation of the Raf-MEK-ERK pathway is required for neutrophil extracellular trap formation. Nat Chem Biol. (2011) 7:75-7. doi: 10.1038/nchembio.496

104. Carestia A, Kaufman T, Rivadeneyra L, Landoni VI, Pozner RG, Negrotto $\mathrm{S}$, et al. Mediators and molecular pathways involved in the regulation of neutrophil extracellular trap formation mediated by activated platelets. $J$ Leukoc Biol. (2016) 99:153-62. doi: 10.1189/jlb.3A0415-161R 
105. Yousefi S, Mihalache C, Kozlowski E, Schmid I, Simon HU. Viable neutrophils release mitochondrial DNA to form neutrophil extracellular traps. Cell Death Differ. (2009) 16:1438-44. doi: 10.1038/cdd.2009.96

106. Yipp BG, Petri B, Salina D, Jenne CN, Scott BN. Infection-induced NETosis is a dynamic process involving neutrophil multitasking in vivo. Nat Med. (2012) 18:1386-93. doi: 10.1038/nm.2847

107. Miao EA, Leaf IA, Treuting PM, Mao DP, Dors M, Sarkar A, et al. Caspase1-induced pyroptosis is an innate immune effector mechanism against intracellular bacteria. Nat Immunol. (2010) 11:1136-42. doi: 10.1038/ni.1960

108. Jorgensen I, Miao EA. Pyroptotic cell death defends against intracellular pathogens. Immunol Rev. (2015) 265:130-42. doi: 10.1111/imr.12287

109. Schroder K, Tschopp J. The inflammasomes. Cell. (2010) 140:821-32. doi: 10.1016/j.cell.2010.01.040

110. Proell M, Gerlic M, Mace PD, Reed JC, Riedl SJ. The CARD plays a critical role in ASC foci formation and inflammasome signalling. Biochem J. (2013) 449:613-21. doi: 10.1042/BJ20121198

111. Agostini L, Martinon F, Burns K, McDermott MF, Hawkins PN, Tschopp J. NALP3 forms an IL-1beta-processing inflammasome with increased activity in Muckle-Wells autoinflammatory disorder. Immunity. (2004) 20:319-25. doi: 10.1016/s1074-7613(04)00046-9

112. Bürckstümmer T, Baumann C, Blüml S, Dixit E, Dürnberger G, Jahn $\mathrm{H}$, et al. An orthogonal proteomic-genomic screen identifies AIM2 as a cytoplasmic DNA sensor for the inflammasome. Nat Immunol. (2009) 10:266-72. doi: 10.1038/ni.1702

113. de Zoete MR, Flavell RA. Detecting "different": Pyrin senses modified GTPases. Cell Res. (2014) 24:1286-7. doi: 10.1038/cr.2014.101

114. Chavarría-Smith J, Vance RE. The NLRP1 inflammasomes. Immunol Rev. (2015) 265:22-34. doi: 10.1111/imr.12283

115. Broz P, Dixit VM. Inflammasomes: mechanism of assembly, regulation and signalling. Nat Rev Immunol. (2016) 16:407-20. doi: 10.1038/nri.2016.58

116. Rathinam VA, Fitzgerald KA. Inflammasome complexes: emerging mechanisms and effector functions. Cell. (2016) 165:792-800. doi: 10.1016/j.cell.2016.03.046

117. Fink SL, Cookson BT. Caspase-1-dependent pore formation during pyroptosis leads to osmotic lysis of infected host macrophages. Cell Microbiol. (2006) 8:1812-25. doi: 10.1111/j.1462-5822.2006.00751.x

118. Bergsbaken T, Cookson BT. Macrophage activation redirects Yersiniainfected host cell death from apoptosis to caspase-1-dependent pyroptosis. PLoS Pathog. (2007) 3:1570-82. doi: 10.1371/journal.ppat.0030161

119. Kovacs SB, Miao EA. Gasdermins: effectors of pyroptosis Trends Cell Biol. (2017) 27:673-84. doi: 10.1016/j.tcb.2017.05.005

120. Fink SL, Bergsbaken T, Cookson BT. Anthrax lethal toxin and Salmonella elicit the common cell death pathway of caspase-1-dependent pyroptosis via distinct mechanisms. Proc Natl Acad Sci USA. (2008) 105:4312-7. doi: 10.1073/pnas.0707370105

121. Chen KW, Groß CJ, Sotomayor FV, Stacey KJ, Tschopp J, Sweet MJ, et al. The Neutrophil NLRC4 inflammasome selectively promotes IL-1 $\beta$ Maturation without pyroptosis during acute salmonella challenge. Cell Rep. (2014) 8:570-82. doi: 10.1016/j.celrep.2014.06.028

122. Hachim MY, Khalil BA, Elemam NM, Maghazachi AA. Pyroptosis: The missing puzzle among innate and adaptive imm.unity crosstalk. J Leukoc Biol. (2020) 108:323-38. doi: 10.1002/JLB.3MIR0120-625R

123. Ryu JC, Kim MJ, Kwon Y, Oh JH, Yoon SS, Shin SJ, et al. Neutrophil pyroptosis mediates pathology of $P$. aeruginosa lung infection in the absence of the NADPH oxidase NOX2. Mucosal Immunol. (2017) 10:757-74. doi: $10.1038 / \mathrm{mi} .2016 .73$

124. Kovacs SB, Oh C, Maltez VI, McGlaughon BD, Verma A, Miao EA, et al. Neutrophil caspase-11 is essential to defend against a cytosol-invasive bacterium. Cell Rep. (2020) 32:107967. doi: 10.1016/j.celrep.2020.107967

125. Dikic I, Elazar Z. Mechanism and medical implications of mammalian autophagy. Nat Rev Mol Cell Biol. (2018) 19:349-64. doi: 10.1038/s41580-018-0003-4

126. Cuervo AM. Autophagy: many paths to the same end. Mol Cell Biochem. (2004) 263:55-72. doi: 10.1023/B:MCBI.0000041848.57020.57

127. Delgado MA, Elmaoued RA, Davis AS, Kyei G, Deretic V. Toll-like receptors control autophagy. EMBO J. (2008) 27:1110-21. doi: 10.1038/emboj. 2008.31
128. Beertsen W, Willenborg M, Everts V, Zirogianni A, Podschun R, Schröder B, et al. Impaired phagosomal maturation in neutrophils leads to periodontitis in lysosomal-associated membrane protein-2 knockout mice. J Immunol. (2008) 180:475-82. doi: 10.4049/jimmunol.180.1.475

129. Mitroulis I, Kourtzelis I, Kambas K, Rafail S, Chrysanthopoulou A, Speletas M, et al. Regulation of the autophagic machinery in human neutrophils. Eur J Immunol. (2010) 40:1461-72. doi: 10.1002/eji.200940025

130. Pliyev BK, Menshikov M. Differential effects of the autophagy inhibitors 3-methyladenine and chloroquine on spontaneous and TNF- $\alpha$-induced neutrophil apoptosis. Apoptosis. (2012) 17:1050-65. doi: 10.1007/s10495-012-0738-x

131. von Gunten S, Simon H-U. Autophagic-like cell death in neutrophils induced by autoantibodies. Autophagy. (2007) 3:67-8. doi: 10.4161/auto.3436

132. Mihalache CC, Yousefi S, Conus S, Villiger PM, Schneider EM, Simon HU. Inflammation-associated autophagy-related programmed necrotic death of human neutrophils characterized by organelle fusion events. J Immunol. (2011) 186:6532-42. doi: 10.4049/jimmunol.1004055

133. Itohm H, Matsuo H, Kitamura N, Yamamoto S, Higuchi T, Takematsu H, et al. Enhancement of neutrophil autophagy by an IVIG preparation against multidrug-resistant bacteria as well as drug-sensitive strains. J Leukoc Biol. (2015) 98:107-17. doi: 10.1189/jlb.4A0813-422RRR

134. Tang S, Zhang Y, Yin SW, Gao XJ, Shi WW, Wang Y, et al. Neutrophil extracellular trap formation is associated with autophagy-related signalling in ANCA-associated vasculitis. Clin Exp Immunol. (2015) 180:408-18. doi: 10.1111/cei.12589

135. Skendros P, Mitroulis I, Ritis K. Autophagy in neutrophils: from granulopoiesis to neutrophil extracellular traps. Front Cell Dev Biol. (2018) 6:109. doi: 10.3389/fcell.2018.00109

136. Huang J, Canadien V, Lam GY, Steinberg BE, Dinauer MC, Magalhaes MA, et al. Activation of antibacterial autophagy by NADPH oxidases. Proc Natl Acad Sci USA. (2009) 106:6226-31. doi: 10.1073/pnas.0811045106

137. Chargui A, Cesaro A, Mimouna S, Fareh M, Brest P, Naquet P, et al. Subversion of autophagy in adherent invasive Escherichia coli-infected neutrophils induces inflammation and cell death. PLoS ONE. (2012) 7:e51727. doi: 10.1371/journal.pone.0051727

138. Chargui A, El May MV. Autophagy mediates neutrophil responses to bacterial infection. APMIS. (2014) 122:1047-58. doi: 10.1111/apm.12271

139. Racanelli AC, Kikkers SA, Choi AMK, Cloonan SM. Autophagy and inflammation in chronic respiratory disease. Autophagy. (2018) 14:221-32. doi: 10.1080/15548627.2017.1389823

140. Germic N, Stojkov D, Oberson K, Yousefi S, Simon H-U. Neither eosinophils nor neutrophils require ATG5-dependent autophagy for extracellular DNA trap formation. Immunology. (2017) 152:517-25. doi: 10.1111/imm.12790

141. Ravichandran KS. Beginnings of a good apoptotic meal: the findme and eat-me signaling pathways. Immunity. (2011) 35:445-55. doi: 10.1016/j.immuni.2011.09.004

142. Bratton DL, Henson PM. Neutrophil clearance: when the party is over, cleanup begins. Trends Immunol. (2011) 32:350-7. doi: 10.1016/j.it.2011.04.009

143. Brown GC, Neher JJ. Eaten alive! Cell death by primary phagocytosis: "Phagoptosis." Trends Biochem Sci. (2012) 37:325-32. doi: 10.1016/j.tibs.2012.05.002

144. Mirnikjoo B, Balasubramanian K, Schroit AJ. Suicidal membrane repair regulates phosphatidylserine externalization during apoptosis. J Biol Chem. (2009) 284:22512-6. doi: 10.1074/jbc.C109.022913

145. Mirnikjoo B, Balasubramanina K, Schroit AJ. Mobilization of lysosomal calcium regulates the externalization of phosphatidylserine during Apoptosis. J Biol Chem. (2009) 284:6918-23. doi: 10.1074/jbc.M805288200

146. Jitkaew S, Witasp E, Zhang S, Kagan VE, Fadeel B. Induction of caspaseand reactive oxygen species-independent phosphatidylserine externalization in primary human neutrophils: role in macrophage recognition and engulfment. J Leukoc Biol. (2009) 85:427-37. doi: 10.1189/jlb.0408232

147. Park Y, Liu G, Lorne EF, Zhao X, Wang J, Tsuruta Y, et al. PAI-1 inhibits neutrophil efferocytosis. Proc Natl Acad Sci USA. (2008) 105:11784-9. doi: 10.1073/pnas.0801394105

148. Segal AW, Dorling J, Coade S. Kinetics of fusion of the cytoplasmic granules with phagocytic vacuoles in human polymorphonuclear leukocytes: 
biochemical and morphological studies. J Cell Biol. (1980) 85:42-59. doi: $10.1083 /$ jcb.85.1.42

149. Johansson A, Jesaitis AJ, Lundqvist H, Magnusson KE, Sjoälin C, Karlsson A, et al. Different subcellular localization of cytochrome $b$ and the dormant NADPH-Oxidase in neutrophils and macrophages: effect on the production of reactive oxygen species during phagocytosis. Cell Immunol. (1995) 161:6171. doi: $10.1006 / \mathrm{cimm} .1995 .1009$

150. Karlsson A, Dahlgren C. Assembly and activation of the neutrophil NADPH oxidase in granule membranes. Antioxid Redox Signal. (2002) 4:49-60. doi: $10.1089 / 152308602753625852$

151. Jankowski A, Scott CC, Grinstein S. Determinants of the phagosomal pH in neutrophils. J Biol Chem. (2002) 277:6059-66. doi: 10.1074/jbc.M110059200

152. Huynh KK, Grinstein S. Regulation of vacuolar ph and its modulation by some microbial species. Microbiol Mol Biol Rev. (2007) 71:452-62. doi: 10.1128/MMBR.00003-07

153. Coakley RJ, Taggart C, McElvaney NG, O’Neill SJ. Cytosolic pH and the inflammatory microenvironment modulate cell death in human neutrophils after phagocytosis. Blood. (2002) 100:3383-91. doi: 10.1182/blood.V100.9.3383

154. Kobayashi SD, Braughton KR, Palazzolo-Balance AM, Kennedy AD, Sampaio E, Kristosturyan E, et al. Rapid neutrophil destruction following phagocytosis of Staphylococcus aureus. J Innate Immun. (2010) 2:560-75. doi: $10.1159 / 000317134$

155. Surewaard BG, de Haas CJ, Vervoort F, Rigby KM, DeLeo FR, Otto $\mathrm{M}$, et al. Staphylococcal alpha-phenol soluble modulins contribute to neutrophil lysis after phagocytosis. Cell Microbiol. (2013) 15:1427-37. doi: $10.1111 / \mathrm{cmi} .12130$

156. William R, Watson G, Redmond HP, Wang JH, Condron C, Bouchier-Hayes D. Neutrophils undergo apoptosis following ingestion of Escherichia coli. J Immunol. (1996) 156:3986-92.

157. Watson RW, Redmond HP, Wang JH, Bouchier-Hayes D. Bacterial ingestion, tumor necrosis factor-alpha, and heat induce programmed cell death in activated neutrophils. Shock. (1996) 5:47-51. doi: 10.1097/00024382-199601000-00010

158. Colamussi ML, White MR, Crouch E, Hartshorn KL. Influenza A virus accelerates neutrophil apoptosis and markedly potentiates apoptotic effects of bacteria. Blood. (1999) 93:2395-403. doi: 10.1182/blood.V93. 7.2395

159. Bergsbaken T, Fink SL, Cookson BT. Pyroptosis: host cell death and inflammation. Nat Rev Microbiol. (2009) 7:99-109. doi: $10.1038 /$ nrmicro2070

160. Yoon KW. Dead cell phagocytosis and innate immune checkpoint. BMB Rep. (2017) 50:496-503. doi: 10.5483/BMBRep.2017.50.10.147

161. Hung SL, Chiang HH, Wu CY, Hsu MJ, Chen YT. Effects of herpes simplex virus type 1 infection on immune functions of human neutrophils. J Periodontal Res. (2012) 47:635-44. doi: 10.1111/j.1600-0765.2012. 01476.x

162. Lukaszewicz A-C, Gontier G, Faivre V, Ouanounou I, Payen D. Elevated production of radical oxygen species by polymorphonuclear neutrophils in cerebrospinal fluid infection. Ann Intensive Care. (2012) 2:10. doi: $10.1186 / 2110-5820-2-10$

163. Fay AJ, Qian X, Jan YN, Jan LY. SK channels mediate NADPH oxidase-independent reactive oxygen species production and apoptosis in granulocytes. Proc Natl Acad Sci USA. (2006) 103:17548-53. doi: 10.1073/pnas.0607914103

164. Carrichon L, Picciocchi A, Debeurme F, Defendi F, Beaumel S, Jesaitis AJ, et al. Characterization of superoxide overproduction by the D-Loop Nox4Nox2 cytochrome b558 in phagocytes-Differential sensitivity to calcium and phosphorylation events. Biochim Biophys Acta. (2011) 1808:78-90. doi: 10.1016/j.bbamem.2010.08.002

165. Pryde JG, Walker A, Rossi AG, Hannah S, Haslett C. Temperaturedependent arrest of neutrophil apoptosis. Failure of Bax insertion into mitochondria at $15{ }^{\circ} \mathrm{C}$ prevents the release of cytochrome c. J Biol Chem. (2000) 275:33574-84. doi: 10.1074/jbc.M001008200

166. Liu CY, Takemasa A, Liles WC, Goodman RB, Jonas M, Rosen H, et al. Broad-spectrum caspase inhibition paradoxically augments cell death in TNF-alpha -stimulated neutrophils. Blood. (2003) 101:295-304. doi: 10.1182/blood-2001-12-0266
167. Maianski NA, Geissler J, Srinivasula SM, Alnemri ES, Roos D, Kuijpers TW. Functional characterization of mitochondria in neutrophils: a role restricted to apoptosis. Cell Death Differ. (2004) 11:143-53. doi: 10.1038/sj.cdd.4401320

168. Kasahara Y, Iwai K, Yachie A, Ohta K, Konno A, Seki H, et al. Involvement of reactive oxygen intermediates in spontaneous and CD95 (Fas/APO-1)-mediated apoptosis of neutrophils. Blood. (1997) 89:1748-53. doi: 10.1182/blood.V89.5.1748

169. Lundqvist-Gustafsson H, Bengtsson T. Activation of the granule pool of the NADPH oxidase accelerates apoptosis in human neutrophils. J Leukoc Biol. (1999) 65:196-204. doi: 10.1002/jlb.65.2.196

170. Shi T, Dansen TB. ROS induced p53 activation: DNA damage, redox signaling or both? Antioxid Redox Signal. (2020) 33:839-59. doi: 10.1089 /ars.2020.8074

171. Tschopp J, Schroder K. NLRP3 inflammasome activation: the convergence of multiple signalling pathways on ROS production? Nat Rev. (2010) 10:210-5. doi: $10.1038 /$ nri2725

172. Sorbara MT, Girardin SE. Mitochondrial ROS fuel the inflammasome. Cell Res. (2011) 21:558-60. doi: 10.1038/cr.2011.20

173. Kwon YW, Masutani H, Nakamura H, Ishii Y, Yodoi J. Redox regulation of cell growth and cell death. Biol Chem. (2003) 384:991-6. doi: 10.1515/BC.2003.111

174. Zhang B, Hirahashi J, Cullere X, Mayadas TN. Elucidation of molecular events leading to neutrophil apoptosis following phagocytosis. Cross-talk between caspase 8 , reactive oxygen species, and MAPK/ERK activation. J Biol Chem. (2003) 278:28443-54. doi: 10.1074/jbc.M210727200

175. Davis RJ. Signal transduction by the JNK group of MAP kinases. Cell. (2000) 103:239-52. doi: 10.1016/S0092-8674(00)00116-1

176. Honda S, Hirata H, Chang L, Maeda S, Karin M, Kamata H. Reactive oxygen species Promote TNF $\alpha$-Induced death and sustained Jnk activation by inhibiting map kinase phosphatases. Cell. (2005) 120:649-61. doi: 10.1016/j.cell.2004.12.041

177. Blomgran R, Zheng L, Stendahl O. Cathepsin-cleaved Bid promotes apoptosis in human neutrophils via oxidative stress-induced lysosomal membrane permeabilization. J Leukoc Biol. (2007) 81:1213-23. doi: 10.1189/jlb.0506359

178. Honda F, Kano H, Kanegane H, Nonoyama S, Kim ES, Lee SK, et al. The kinase Btk negatively regulates the production of reactive oxygen species and stimulation-induced apoptosis in human neutrophils. Nat Immunol. (2012) 13:369-78. doi: 10.1038/ni.2234

179. Blomgran R, Zheng L, Stendahl O. Uropathogenic Escherichia coli TRIGGERS OXYGEN-DEPENDENT APOPTOSIS IN HUMAN NEUTROPHILS THROUGH THE COOPERATIVE EFFECT OF TYPE 1 FIMBRIAE AND LIPOPOLYSACCHARIDE. Infect Immun. (2004) 72:4570-8. doi: 10.1128/IAI.72.8.4570-4578.2004

180. Ward C, Wong TH, Murray J, Rahman I, Haslett C, Chilvers ER, et al. Induction of human neutrophil apoptosis by nitric oxide donors: evidence for a caspase-dependent, cyclic-GMP-independent, mechanism. Biochem Pharmacol. (2000) 59:305-14. doi: 10.1016/S0006-2952(99)00329-9

181. Blaylock MG, Cuthbertson BH, Galley HF, Ferguson NR, Webster NR. The effect of nitric oxide and peroxynitrite on apoptosis in human polymorphonuclear leukocytes. Free Radic Biol Med. (1998) 25:748-52. doi: 10.1016/S0891-5849(98)00108-7

182. Fortenberry JD, Owens ML, Brown MR, Atkinson D, Brown LA. Exogenous nitric oxide enhances neutrophil cell death and dna fragmentation. Am J Respir Cell Mol Biol. (1998) 18:421-8. doi: 10.1165/ajrcmb.18.3.2875

183. Taylor EL, Megson IL, Haslett C, Rossi AG. Nitric oxide: a key regulator of myeloid inflammatory cell apoptosis. Cell Death Differ. (2003) 10:418-30. doi: $10.1038 /$ sj.cdd. 4401152

184. Taylor EL, Rossi AG, Shaw CA, Dal Rio FP, Haslett C, Megson IL. GEA 3162 decomposes to co-generate nitric oxide and superoxide and induces apoptosis in human neutrophils via a peroxynitrite-dependent mechanism. Br J Pharmacol. (2004) 143:179-85. doi: 10.1038/sj.bjp.0705909

185. Johansson AC, Appelqvist H, Nilsson C, Kågedal K, Roberg K, Öllinger K. Regulation of apoptosis-associated lysosomal membrane permeabilization. Apoptosis. (2010) 15:527-40. doi: 10.1007/s10495-009-0452-5

186. Earnshaw WC, Martins LM, Kaufmann SH. Mammalian caspases: structure, activation, substrates, and functions during apoptosis. Annu Rev Biochem. (1999) 68:383-424. doi: 10.1146/annurev.biochem.68.1.383 
187. Kaufmann SH, Kottke TJ, Martins LM, Henzing AJ, Earnshaw WC. Analysis of Caspase Activation During Apoptosis. Curr Protoc Cell Biol. (2001) 11:18.2.1-29. doi: 10.1002/0471143030.cb1802s11

188. Aref S, Abdullah D, Fouda M, El Menshawy N, Azmy E, Bassam A, et al. Neutrophil apoptosis in neutropenic patients with hepatitis c infection: role of caspases 3, 10, and GM-CSF. Indian J Hematol Blood Transfus. (2011) 27:81-7. doi: 10.1007/s12288-011-0067-1

189. Pérez-Figueroa E, Torres J, Sánchez-Zauco N, Contreras-Ramos A, AlvarezArellano L, Pérez-Figueroa E, et al. Activation of NLRP3 inflammasome in human neutrophils by Helicobacter pylori infection. Innate Immun. (2016) 22:103-12. doi: 10.1177/1753425915619475

190. Smith MA, Schnellmann RG. Calpains, mitochondria, and apoptosis. Cardiovasc Res. (2012) 96:32-7. doi: 10.1093/cvr/cvs163

191. Goll DE, Thompson VF, Li H, Wei W, Cong J. The calpain system. Physiol Rev. (2003) 83:731-801. doi: 10.1152/physrev.00029.2002

192. Altznauer F, Conus S, Cavalli A, Folkers G, Simon HU. Calpain-1 regulates bax and subsequent smac-dependent caspase-3 activation in neutrophil apoptosis. J Biol Chem. (2004) 279:5947-57. doi: 10.1074/jbc.M308576200

193. Wiemer AJ, Lokuta MA, Surfus JC, Wernimont SA, Huttenlocher A. Calpain inhibition impairs TNF- $\alpha$-mediated neutrophil adhesion, arrest and oxidative burst. Mol Immunol. (2010) 47:894-902. doi: 10.1016/j.molimm.2009.10.002

194. Fujita H, Kato T, Watanabe N, Takahashi T, Kitagawa S. Calpain inhibitors stimulate phagocyte functions via activation of human formyl peptide receptors. Arch Biochem Biophys. (2011) 513:51-60. doi: 10.1016/j.abb.2011.06.007

195. Maianski NA, Roos D, Kuijpers TW. Bid truncation, bid/bax targeting to the mitochondria, and caspase activation associated with neutrophil apoptosis are inhibited by granulocyte colony-stimulating factor. J Immunol. (2004) 172:7024-30. doi: 10.4049/jimmunol.172.11.7024

196. Murphy BM, O'Neill AJ, Adrain C, Watson RW, Martin SJ. The apoptosome pathway to caspase activation in primary human neutrophils exhibits dramatically reduced requirements for cytochrome c. J Exp Med. (2003) 197:625-32. doi: 10.1084/jem.20021862

197. Fossati G, Moulding DA, Spiller DG, Moots RJ, White MR, Edwards SW. The mitochondrial network of human neutrophils: role in chemotaxis, phagocytosis, respiratory burst activation, and commitment to apoptosis. $J$ Immunol. (2003) 170:1964-72. doi: 10.4049/jimmunol.170.4.1964

198. Zhang J, He J, Xia J, Chen Z, Chen X. Delayed apoptosis by neutrophils from COPD patients is associated with altered bak, bcl-xl, and mcl-1 mRNA expression. Diagn Pathol. 7:65. doi: 10.1186/1746-1596-7-65

199. Cowburn AS, Summers C, Dunmore BJ, Farahi N, Hayhoe RP, Print CG, et al. Granulocyte/macrophage colony-stimulating factor causes a paradoxical increase in the bh3-only pro-apoptotic protein bim in human neutrophils. Am J Respir Cell Mol Biol. (2011) 44:879-87. doi: $10.1165 / \mathrm{rcmb} .2010-01010 \mathrm{OC}$

200. Moulding DA, Quayle JA, Hart CA, Edwards SW. Mcl1 expression in human neutrophils: regulation by cytokines and correlation with cell survival. Blood. (1998) 92:2495-502. doi: 10.1182/blood.V92.7.2495.2495_2495_2502

201. Akgul C, Edwards SW. Regulation of neutrophil apoptosis via death receptors. Cell Mol Life Sci. (2003) 60:2402-8. doi: $10.1007 / \mathrm{s} 00018-003-3110-\mathrm{z}$

202. O'Neill AJ, Doyle BT, Molloy E, Watson C, Phelan D, Greenan MC, et al. Gene expression profile of inflammatory neutrophils: alterations in the inhibitors of apoptosis proteins during spontaneous and delayed apoptosis. Shock. (2004) 21:512-8. doi: 10.1097/01.shk.0000123512.13212.ca

203. Sakamoto E. Type I and type II interferons delay human neutrophil apoptosis via activation of STAT3 and up-regulation of cellular inhibitor of apoptosis 2. J Leukoc Biol. (2005) 78:301-9. doi: 10.1189/jlb.1104690

204. François S, El Benna J, Dang PM, Pedruzzi E, Gougerot-Pocidalo MA, Elbim C. Inhibition of neutrophil apoptosis by tlr agonists in whole blood: involvement of the phosphoinositide 3-kinase/akt and nf-kb signaling pathways, leading to increased levels of mcl-1, al, and phosphorylated Bad. $J$ Immunol. (2005) 174:3633-42. doi: 10.4049/jimmunol.174.6.3633

205. Tsukahara Y, Lian Z, Zhang X, Whitney C, Kluger Y, Tuck D, et al. Gene expression in human neutrophils during activation and priming by bacterial lipopolysaccharide. J Cell Biochem. (2003) 89:848-61. doi: 10.1002/jcb.10526
206. Wei S, Liu JH, Epling-Burnette PK, Gamero AM, Ussery D, Pearson EW, et al. Critical role of Lyn kinase in inhibition of neutrophil apoptosis by granulocyte-macrophage colony-stimulating factor. J Immunol. (1996) 157:5155-62.

207. Yasui K, Sekiguchi Y, Ichikawa M, Nagumo H, Yamazaki T. Granulocyte macrophage-colony stimulating factor delays neutrophil apoptosis and primes its function through Ia-type phosphoinositide 3-kinase. J Leukoc Biol. (2002) 72:1020-6. doi: 10.1189/jlb.72.5.1020

208. Kobayashi SD. Spontaneous neutrophil apoptosis and regulation of cell survival by granulocyte macrophage-colony stimulating factor. J Leukoc Biol. (2005) 78:1408-18. doi: 10.1189/jlb.0605289

209. Maianski NA. Granulocyte colony-stimulating factor inhibits the mitochondria-dependent activation of caspase-3 in neutrophils. Blood. (2002) 99:672-9. doi: 10.1182/blood.V99.2.672

210. Bruno A, Conus S, Schmid I, Simon H-U. Apoptotic pathways are inhibited by leptin receptor activation in neutrophils. J Immunol. (2014) 174:8090-6. doi: 10.4049/jimmunol.174.12.8090

211. El Kebir D, József L, Khreiss T, Filep JG. Inhibition of K+ efflux prevents mitochondrial dysfunction, and suppresses caspase-3-, apoptosis-inducing factor-, and endonuclease G-mediated constitutive apoptosis in human neutrophils. Cell Signal. (2006) 18:2302-13. doi: 10.1016/j.cellsig.2006. 05.013

212. Coxon A, Tang T, Mayadas TN. Cytokine-activated endothelial cells delay neutrophil apoptosis in vitro and in vivo. J Exp Med. (1999) 190:923-34. doi: 10.1084 /jem.190.7.923

213. Ross EA, Douglas MR, Wong SH, Ross EJ, Curnow SJ, Nash GB, et al. Interaction between integrin $\alpha 9 \beta 1$ and vascular cell adhesion molecule1 (VCAM-1) inhibits neutrophil apoptosis. Blood. (2006) 107:1178-83. doi: 10.1182/blood-2005-07-2692

214. Costantini C, Micheletti A, Calzetti F, Perbellini O, Pizzolo G, Cassatella MA. Neutrophil activation and survival are modulated by interaction with NK cells. Int Immunol. (2010) 22:827-38. doi: 10.1093/intimm/dxq434

215. Bae HB, Zmijewski JW, Deshane JS, Zhi D, Thompson LC, Peterson CB, et al. Vitronectin inhibits neutrophil apoptosis through activation of integrinassociated signaling pathways. Am J Respir Cell Mol Biol. (2012) 46:790-6. doi: 10.1165/rcmb.2011-0187OC

216. Zmijewski JW, Bae HB, Deshane JS, Peterson CB, Chaplin DD, Abraham E. Inhibition of neutrophil apoptosis by PAI-1. Am J Physiol Cell Mol Physiol. (2011) 301:L247-54. doi: 10.1152/ajplung.00075.2011

217. Van Den Berg JM, Weyer S, Roos D, Kuijpers TW, Weening JJ. Divergent effects of tumor necrosis factor $\alpha$ on apoptosis of human neutrophils. $J$ Leukoc Biol. (2001) 69:467-73. doi: 10.1189/jlb.69.3.467

218. Wright HL, Chikura B, Bucknall RC, Moots RJ, Edwards SW. Changes in expression of membrane TNF, NF- $\mathrm{kB}$ activation and neutrophil apoptosis during active and resolved inflammation. Ann Rheum Dis. (2011) 70:537-43. doi: 10.1136/ard.2010.138065

219. Dyugovskaya L, Polyakov A, Ginsberg D, Lavie P, Lavie L. Molecular pathways of spontaneous and TNF- $\alpha$-mediated neutrophil apoptosis under intermittent hypoxia. Am J Respir Cell Mol Biol. (2011) 45:154-62. doi: $10.1165 / \mathrm{rcmb} .2010-0025 \mathrm{OC}$

220. Maianski NA, Roos D, Kuijpers TW. Tumor necrosis factor $\alpha$ induces a caspase-independent death pathway in human neutrophils. Blood. (2003) 101:1987-95. doi: 10.1182/blood-2002-02-0522

221. Kilpatrick LE, Lee JY, Haines KM, Campbell DE, Sullivan KE, Korchak HM. A role for PKC- $\delta$ and PI 3-kinase in TNF- $\alpha$-mediated antiapoptotic signaling in the human neutrophil. Am J Physiol Cell Physiol. (2003) 283:C48-57. doi: 10.1152/ajpcell.00385.2001

222. Dunican AL, Leuenroth SJ, Grutkoski P, Ayala A, Simms HH. TNF $\alpha$-induced suppression of PMN apoptosis is mediated through interleukin-8 production. Shock. (2000) 14:284-9. doi: 10.1097/00024382-200014030-00007

223. Cowburn AS, Deighton J, Walmsley SR, Chilvers ER. The survival effect of TNF- $\alpha$ in human neutrophils is mediated via NF-KB-dependent IL-8 release. Eur J Immunol. (2004) 34:1733-43. doi: 10.1002/eji.2004 25091

224. Renshaw SA, Timmons SJ, Eaton V, Usher LR, Akil M, Bingle CD, et al. Inflammatory neutrophils retain susceptibility to apoptosis mediated via the Fas death receptor. J Leukoc Biol. (2000) 67:662-8. doi: 10.1002/jlb.67.5.662 
225. Sharma R, Sharma A, Dwivedi S, Zimniak P, Awasthi S, Awasthi YC. 4hydroxynonenal self-limits fas-mediated DISC-independent apoptosis by promoting export of daxx from the nucleus to the cytosol and its binding to fas. Biochemistry. (2008) 47:143-56. doi: 10.1021/bi701559f

226. Wajant H, Pfizenmaier K, Scheurich P. Tumor necrosis factor signaling. Cell Death Differ. (2003) 10:45-65. doi: 10.1038/sj.cdd.4401189

227. Harper N, Farrow SN, Kaptein A, Cohen GM, MacFarlane M. Modulation of tumor necrosis factor apoptosis-inducing ligand- induced NF-kappa B activation by inhibition of apical caspases. J Biol Chem. (2001) 276:34743-52. doi: 10.1074/jbc.M105693200

228. Xie P. TRAF molecules in cell signaling and in human diseases. J Mol Signal. (2013) 8:7. doi: 10.1186/1750-2187-8-7

229. Watson RW, O’Neill A, Brannigan AE, Coffey R, Marshall JC, Brady $\mathrm{HR}$, et al. Regulation of Fas antibody induced neutrophil apoptosis is both caspase and mitochondrial dependent. FEBS. (1999) 453:67-71. doi: 10.1016/S0014-5793(99)00688-2

230. Croker BA, O’Donnell JA, Nowell CJ, Metcalf D, Dewson G, Campbell KJ, et al. Fas-mediated neutrophil apoptosis is accelerated by Bid, Bak, and Bax and inhibited by Bcl-2 and Mcl-1. Proc Natl Acad Sci USA. (2011) 108:13135-40. doi: 10.1073/pnas.1110358108

231. Fecho K, Cohen PL. Fas ligand (gld) and Fas (lpr) deficient mice do not show alterations in the extravasation or apoptosis of inflammatory neutrophils. $J$ Leukoc Biol. (1998) 64:373-83. doi: 10.1002/jlb.64.3.373

232. Villunger A, O'Reilly LA, Holler N, Adams J, Strasser A. FAS Ligand, Bcl2, granulocyte colony-stimulating factor, and p38 mitogen-activated protein kinase. J Exp Med. (2000) 192:647-58. doi: 10.1084/jem.192.5.647

233. Brown SB, Savill J. Phagocytosis triggers macrophage release of Fas ligand and induces apoptosis of bystander leukocytes. J Immunol. (1999) 162:480-5.

234. Kamohara H, Matsuyama W, Shimozato O, Abe K, Galligan C, Hashimoto $S$, et al. Regulation of tumour necrosis factor-related apoptosis-inducing ligand (TRAIL) and TRAIL receptor expression in human neutrophils. Immunology. (2004) 111:186-94. doi: 10.1111/j.0019-2805.2003.01794.x

235. Koga Y, Matsuzaki A, Suminoe A, Hattori H, Hara T. Neutrophil-Derived TNF-Related Apoptosis-Inducing Ligand (TRAIL): a novel mechanism of antitumor effect by neutrophils. Cancer Res. (2004) 64:1037-43. doi: 10.1158/0008-5472.CAN-03-1808

236. Renshaw SA, Parmar JS, Singleton V, Rowe SJ, Dockrell DH, Dower SK, et al. Acceleration of human neutrophil apoptosis by TRAIL. J Immunol. (2003) 170:1027-33. doi: 10.4049/jimmunol.170.2.1027

237. Lum JJ, Bren G, McClure R, Badley AD. Elimination of senescent neutrophils by TNF-related apopotosis-inducing ligand. J Immunol. (2005) 175:1232-8. doi: 10.4049/jimmunol.175.2.1232

238. McGrath EE, Marriott HM, Lawrie A, Francis SE, Sabroe I, Renshaw SA, et al. TNF-related apoptosis-inducing ligand (TRAIL) regulates inflammatory neutrophil apoptosis and enhances resolution of inflammation. J Leukoc Biol. (2011) 90:855-65. doi: 10.1189/jlb.0211062

239. Simons MP, Nauseef WM, Griffith TS. Neutrophils and TRAIL: insights into BCG immunotherapy for bladder cancer. Immunol Res. (2007) 39:79-93. doi: 10.1007/s12026-007-0084-1

240. Gray RD, Hardisty G, Regan KH, Smith M, Robb CT, Duffin R, et al. Delayed neutrophil apoptosis enhances NET formation in cystic fibrosis. Thorax. (2018) 73:134-44. doi: 10.1136/thoraxjnl-2017-210134

241. Barrera L, Montes-Servín E, Hernandez-Martinez JM, García-Vicente MLÁ, Montes-Servín E, Herrera-Martínez M, et al. CD47 overexpression is associated with decreased neutrophil apoptosis/phagocytosis and poor prognosis in non-small-cell lung cancer patients. Br J Cancer. (2017) 117:385-97. doi: 10.1038/bjc.2017.173

242. Uddin M, Nong G, Ward J, Seumois G, Prince LR, Wilson SJ, et al. Prosurvival activity for airway neutrophils in severe asthma. Thorax. (2010) 65:684-9. doi: 10.1136/thx.2009.120741

243. Grunwell JR, Stephenson ST, Tirouvanziam R, Brown LAS, Brown MR, Fitzpatrick AM. Children with neutrophil-predominant severe asthma have proinflammatory neutrophils with enhanced survival and impaired clearance. J Allergy Clin Immunol Pract. (2019) 7:516-525.e6. doi: 10.1016/j.jaip.2018.08.024

244. Quint JK, Wedzicha JA. The neutrophil in chronic obstructive pulmonary disease. J Allergy Clin Immunol. (2007) 119:1065-71. doi: $10.1016 /$ j.jaci.2006.12.640
245. Pletz MW, Ioanas M, de Roux A, Burkhardt O, Lode H. Reduced spontaneous apoptosis in peripheral blood neutrophils during exacerbation of COPD. Eur Respir J.. (2004) 532-7. doi: 10.1183/09031936.04.00089004

246. Fialkow L, Fochesatto Filho L, Bozzetti MC, Milani AR, Rodrigues Filho EM, Ladniuk RM, et al. Neutrophil apoptosis: a marker of disease severity in sepsis and sepsis-induced acute respiratory distress syndrome. Crit Care. (2006) 10:R155. doi: 10.1186/cc5090

247. Zhang C, Shu W, Zhou G, Lin J, Chu F, Wu H, et al. Anti-TNF$\alpha$ therapy suppresses proinflammatory activities of mucosal neutrophils in inflammatory bowel disease. Mediators Inflamm. (2018) 2018:3021. doi: $10.1155 / 2018 / 3021863$

248. Rossi AG, Sawatzky DA, Walker A, Ward C, Sheldrake TA, Riley NA, et al. Cyclin-dependent kinase inhibitors enhance the resolution of inflammation by promoting inflammatory cell apoptosis. Nat Med. (2006) 12:1434. doi: 10.1038/nm1206-1434

249. Courtney PA, Crockard AD, Williamson K, Irvine AE, Kennedy RJ, Bell AL. Increased apoptotic peripheral blood neutrophils in systemic lupus erythematosus: relations with disease activity, antibodies to double stranded DNA. and neutropenia. Ann Rheum Dis. (1999) 58:309-14. doi: 10.1136/ard.58.5.309

250. Fukushi T, Yamamoto T, Yoshida M, Fujikura E, Miyazaki M, Nakayama M. Enhanced neutrophil apoptosis accompanying myeloperoxidase release during hemodialysis. Sci Rep. (2020) 10:21747. doi: 10.1038/s41598-020-78742-z

251. Aprikyan AA, Liles WC, Park JR, Jonas M, Chi EY, Dale DC. Myelokathexis, a congenital disorder of severe neutropenia characterized by accelerated apoptosis and defective expression of bcl-x in neutrophil precursors. Blood. (2000) 95:320-7. doi: 10.1182/blood.V95.1.320

252. McDonald B, Urrutia R, Yipp BG, Jenne CN, Kubes P. Intravascular neutrophil extracellular traps capture bacteria from the bloodstream during sepsis. Cell Host Microbe. (2012) 12:324-33. doi: 10.1016/j.chom.2012.06.011

253. Tanaka K, Koike Y, Shimura T, Okigami M, Ide S, Toiyama Y, et al. In vivo characterization of neutrophil extracellular traps in various organs of a murine sepsis model. PLoS ONE. (2014) 9:e111888. doi: 10.1371/journal.pone.0111888

254. Sakurai K, Miyashita T, Okazaki M, Yamaguchi T, Ohbatake Y, Nakanuma S, et al. Role for Neutrophil Extracellular Traps (NETs) and platelet aggregation in early sepsis-induced hepatic dysfunction. In vivo. (2017) 31:1051-8. doi: 10.21873/invivo.11169

255. Semeraro F, Ammollo CT, Morrissey JH, Dale GL, Friese P, Esmon NL, et al. Extracellular histones promote thrombin generation through plateletdependent mechanisms: involvement of platelet TLR2 and TLR4. Blood. (2011) 118:1952-61. doi: 10.1182/blood-2011-03-343061

256. Noubouossie DF, Reeves BN, Strahl BD, Key NS. Neutrophils: back in the thrombosis spotlight. Blood. (2019) 133:2186-97. doi: 10.1182/blood-2018-10-862243

257. Clark SR, Ma AC, Tavener SA, McDonald B, Goodarzi Z, Kelly MM, et al. Platelet TLR4 activates neutrophil extracellular traps to ensnare bacteria in septic blood. Nat Med. (2007) 13:463-9. doi: 10.1038/nm1565

258. Hakkim A, Fürnrohr BG, Amann K, Laube B, Abed UA, Brinkmann $\mathrm{V}$, et al. Impairment of neutrophil extracellular trap degradation is associated with lupus nephritis. Proc Natl Acad Sci USA. (2010) 107:9813-8. doi: 10.1073/pnas.0909927107

259. Tomar B, Anders HJ, Desai J, Mulay SR. Neutrophils and neutrophil extracellular traps drive necroinflammation in COVID-19. Cells. (2020) 9:1383. doi: 10.3390/cells9061383

260. Veras FP, Pontelli MC, Silva CM, Toller-Kawahisa JE, de Lima M, Nascimento DC, et al. SARS-CoV-2-triggered neutrophil extracellular traps mediate COVID-19 pathology. J Exp Med. (2020) 217:e20201129. doi: 10.1084/jem.20201129

261. Wang J, Li Q, Yin Y, Zhang Y, Cao Y, Lin X, et al. Excessive neutrophils and neutrophil extracellular traps in COVID-19. Front Immunol. (2020) 11:2063. doi: 10.3389/fimmu.2020.02063

262. Zuo Y, Yalavarthi S, Shi H, Gockman K, Zuo M, Madison JA, et al. Neutrophil extracellular traps (NETs) as markers of disease severity in COVID-19. medRxiv [Preprint]. (2020). doi: 10.1101/2020.04.09.20059626

263. Chaput C, Zychlinsky A. Sepsis: the dark side of histones. Nat Med. (2009) 15:1245-46. doi: 10.1038/nm1109-1245 
264. Xu Z, Huang Y, Mao P, Zhang J, Li Y. Sepsis and ARDS: the dark side of histones. Mediators Inflamm. (2009) 2015:205054. doi: 10.1155/2015/205054

265. Lv X, Wen T, Song J, Xie D, Wu L, Jiang X, et al. Extracellular histones are clinically relevant mediators in the pathogenesis of acute respiratory distress syndrome. Respir Res. (2017) 18:165. doi: 10.1186/s12931-017-0651-5

266. Wygrecka M, Kosanovic D, Wujak L, Reppe K, Henneke I, Frey $\mathrm{H}$, et al. Antihistone Properties of $\mathrm{C} 1$ esterase inhibitor protect against lung injury. Am J Respir Crit Care Med. (2017)196:186-99. doi: 10.1164/rccm.201604-0712OC

267. Manzenreiter R, Kienberger F, Marcos V, Schilcher K, Krautgartner WD, Obermayer A, et al. Ultrastructural characterization of cystic fibrosis sputum using atomic force and scanning electron microscopy. J Cyst Fibros. (2012) 11:84-92. doi: 10.1016/j.jcf.2011.09.008

268. Fuchs TA, Brill A, Wagner DD. Neutrophil extracellular trap (NET) impact on deep vein thrombosis. Arterioscler Thromb Vasc Biol. (2012) 32:1777-83. doi: 10.1161/ATVBAHA.111.242859

269. Laridan E, Martinod K, De Meyer SF. Neutrophil extracellular traps in arterial and venous thrombosis. Semin Thromb Hemost. (2019) 45:86-93. doi: $10.1055 / \mathrm{s}-0038-1677040$

270. Zhang Z, Xie G, Liang L, Liu H, Pan J, Cheng H, et al. RIPK3-mediated necroptosis and neutrophil infiltration are associated with poor prognosis in patients with alcoholic cirrhosis. J Immunol Res. (2018) 2018:1509851. doi: $10.1155 / 2018 / 1509851$

271. Calabrese LH, Rose-John S. IL-6 biology: implications for clinical targeting in rheumatic disease. Nat Rev Rheumatol. (2014) 10:720-7. doi: 10.1038/nrrheum.2014.127

272. Mehta P, McAuley DF, Brown M, Sanchez E, Tattersall RS, Manson JJ, HLH, et al. COVID-19: consider cytokine storm syndromes and immunosuppression. Lancet. (2020) 395:1033-4. doi: $10.1016 / \mathrm{S} 0140-6736(20) 30628-0$

273. Kessenbrock K, Krumbholz M, Schönermarck U, Back W, Gross WL, Werb $Z$, et al. Netting neutrophils in autoimmune small-vessel vasculitis. Nat Med. (2009) 15:623-5. doi: 10.1038/nm.1959

274. Papayannopoulos V. Neutrophil extracellular traps in immunity and disease. Nat Rev Immunol. (2018) 18:134-47. doi: 10.1038/nri.2017.105

275. Ouwendijk WJD, Raadsen MP, van Kampen JJA, Verdijk RM, von der Thusen JH, Guo L, et al. Neutrophil extracellular traps persist at high levels in the lower respiratory tract of critically ill COVID-19 patients. J Infect Dis. (2021). doi: 10.1093/infdis/jiab053. [Epub ahead of print].

276. Olcay L, Yetgin S, Erdemli E, Germeshausen M, Aktas D, Büyükaşik Y, et al. Congenital dysgranulopoietic neutropenia. Pediatr Blood Cancer. (2008) 50:115-9. doi: $10.1002 / \mathrm{pbc} .20877$

277. Liu L, Sun B. Neutrophil pyroptosis: new perspectives on sepsis. Cell Mol Life Sci. (2019) 76:2031-42. doi: 10.1007/s00018-019-03060-1
278. Savill JS, Henson PM, Haslett C. Phagocytosis of aged human neutrophils by macrophages is mediated by a novel "charge-sensitive" recognition mechanism. J Clin Invest. (1989) 84:1518-27. doi: 10.1172/ JCI114328

279. Rydell-Törmänen K, Uller L, Erjefält JS. Direct evidence of secondary necrosis of neutrophils during intense lung inflammation. Eur Respir J. (2006) 28:268-74. doi: 10.1183/09031936.06.00126905

280. Bylund J, Campsall PA, Ma RC, Conway BA, Speert DP. Burkholderia cenocepacia induces neutrophil necrosis in chronic granulomatous disease. $J$ Immunol. (2005) 174:3562-9. doi: 10.4049/jimmunol.174.6.3562

281. Naylor EJ, Bakstad D, Biffen M, Thong B, Calverley P, Scott S, et al. Haemophilus influenzae induces neutrophil necrosis: a role in chronic obstructive pulmonary disease? Am J Respir Cell Mol Biol. (2007) 37:135-43. doi: $10.1165 / \mathrm{rcmb} .2006-0375 \mathrm{OC}$

282. Han J, Zhong CQ, Zhang DW. Programmed necrosis: backup to and competitor with apoptosis in the immune system. Nat Immunol. (2011) 12:1143-9. doi: 10.1038/ni.2159

283. Alemán OR, Mora N, Cortes-Vieyra R, Uribe-Querol E, Rosales C. Differential use of human neutrophil fc $\gamma$ receptors for inducing neutrophil extracellular trap formation. J Immunol Res. (2016) 2016:2908034. doi: $10.1155 / 2016 / 2908034$

284. Hosseinzadeh A, Thompson PR, Segal BH, Urban CF. Nicotine induces neutrophil extracellular traps. J Leukoc Biol. (2016) 100:1105-12. doi: 10.1189/jlb.3AB0815-379RR

285. Clark HL, Abbondante S, Minns MS, Greenberg EN, Sun Y, Pearlman E. Protein Deiminase 4 and CR3 regulate aspergillus fumigatus and $\beta$-glucan-induced neutrophil extracellular trap formation, but hyphal killing is dependent only on CR3. Front Immunol. (2018) 9:1182. doi: 10.3389/fimmu.2018.01182

286. Gupta S, Kaplan MJ. The role of neutrophils and NETosis in autoimmune and renal diseases. Nat Rev Nephrol. (2016) 12:402-13 1. doi: 10.1038/nrneph.2016.71

Conflict of Interest: The authors declare that the research was conducted in the absence of any commercial or financial relationships that could be construed as a potential conflict of interest.

Copyright () 2021 Pérez-Figueroa, Álvarez-Carrasco, Ortega and MaldonadoBernal. This is an open-access article distributed under the terms of the Creative Commons Attribution License (CC BY). The use, distribution or reproduction in other forums is permitted, provided the original author(s) and the copyright owner(s) are credited and that the original publication in this journal is cited, in accordance with accepted academic practice. No use, distribution or reproduction is permitted which does not comply with these terms. 